\title{
On the chemical dynamics of extracellular polysaccharides in the high Arctic surface microlayer
}

\author{
Q. Gao ${ }^{1}$, C. Leck $^{1}$, C. Rauschenberg ${ }^{2}$, and P. A. Matrai ${ }^{2}$ \\ ${ }^{1}$ Department of Meteorology, Stockholm University, 10691 Stockholm, Sweden \\ ${ }^{2}$ Bigelow Laboratory for Ocean Sciences, West Boothbay Harbor, ME 04575, USA \\ Correspondence to: Q. Gao (gao@misu.su.se) \\ Received: 27 December 2011 - Published in Ocean Sci. Discuss.: 18 January 2012 \\ Revised: 27 May 2012 - Accepted: 29 May 2012 - Published: 5 July 2012
}

\begin{abstract}
The surface microlayer (SML) represents a unique system of which the physicochemical characteristics may differ from those of the underlying subsurface seawater (SSW). Within the Arctic pack ice area, the SML has been characterized as enriched in small colloids of biological origin, resulting from extracellular polymeric secretions (EPS). During the Arctic Summer Cloud Ocean Study (ASCOS) in August 2008, particulate organic matter (POM, with size range $>0.22 \mu \mathrm{m}$ ) and dissolved organic matter (DOM, $<0.22 \mu \mathrm{m}$, obtained after filtration) samples were collected and chemically characterized from the SML and the corresponding SSW at an open lead centered at $87.5^{\circ} \mathrm{N}$ and $5^{\circ} \mathrm{E}$. Total organic carbon was persistently enriched in the SML with a mean enrichment factor (EF) of $1.45 \pm 0.41$, whereas sporadic depletions of dissolved carbohydrates and amino acids were observed. Monosaccharide compositional analysis reveals that EPS in the Arctic lead was formed mainly of distinctive heteropolysaccharides, enriched in xylose, fucose and glucose. The mean concentrations of total hydrolysable neutral sugars in SSW were $94.9 \pm 37.5 \mathrm{nM}$ in high molecular weight (HMW) DOM ( $>5 \mathrm{kDa}$ ) and $64.4 \pm 14.5 \mathrm{nM}$ in POM. The enrichment of polysaccharides in the SML appeared to be a common feature, with EFs ranging from 1.7 to 7.0 for particulate polysaccharides and 3.5 to 12.1 for polysaccharides in the HMW DOM fraction. A calculated monosaccharide yield suggests that polymers in the HMW DOM fraction were scavenged, without substantial degradation, into the SML. Bubble scavenging experiments showed that newly aggregated particles could be formed abiotically by coagulation of low molecular weight nanometer-sized gels. Aerosol particles, artificially generated by bubbling experiments, were enriched in polysaccharides by factors of $22-70$, relative to
\end{abstract}

the source seawater. We propose that bubble scavenging of surface-active polysaccharides could be one of the possible mechanisms for the enrichment of polysaccharides in the high Arctic open lead SML.

\section{Introduction}

Low-altitude clouds play a particularly important role in the Arctic climate and are the most important factor regulating the surface radiation budget and thus the melting or freezing of the Arctic sea ice (Intrieri et al., 2002; Sedlar et al., 2011). Therefore, it is essential to accurately understand their formation and properties in the region. The reflection of sunlight by clouds is directly dependent on their microphysical properties, including the number and sizes of the cloud drops. In turn, these microphysical properties are dependent on chemical properties, state of mixture, and morphology of the cloud condensation nuclei $(\mathrm{CCN})$, which is the number of aerosol particles available for uptake or condensation of water vapor.

Recent results have clearly demonstrated that biogenic microcolloids (also called exopolymer secretions, EPS), shown to be polymer microgels (Chin et al., 1998; Orellana et al., 2003, 2011), are produced by phytoplankton and sea ice algae biological secretions and, due to their emergent properties, could constitute an important source of $\mathrm{CCN}$ in the pristine high Arctic summer sea ice (Orellana et al., 2011). These results verify past studies of the aerosol-cloud relationship over the Arctic pack ice area (Leck and Bigg, 1999, 2005b, 2010; Leck et al., 2002; Bigg and Leck, 2008). Fresh aggregates of microcolloids could act as CCN directly because of the gel's strong surface-active properties. 
Despite being predominately hydrophobic in nature (with growth factors slightly above 1), the marine gels have effectively a higher $\mathrm{CCN}$ activation efficiency than more soluble, but inorganic aerosol (Ovadnevaite et al., 2011). When surface tension counteracts water activity, the net effect is an enhancement of particle CCN activity. This is in agreement with a model study by Lohmann and Leck (2005) that found it necessary to invoke a highly surface-active Aitken mode of aerosol particles, assumed to be polymer gels, in order to explain the observed $\mathrm{CCN}$ over the pack ice, collected under clear sky and ice-melting conditions. However, a more recent study by Martin et al. (2011), on the CCN behavior of particles sampled over the Arctic pack ice, suggests that marine biogenic organics, rather than promoting the formation of CCN, suppress the CCN activity of aerosol particles. This was in agreement with previous findings by Leck et al. (2002) for cloudy, rather than clear sky, conditions over the pack ice and laboratory simulations by Fuentes et al. (2011). One likely explanation for the apparent disagreement is that the above observations likely represented either a hydrophobic microcolloid population covered with a surfactant gel (Leck et al., 2002; Ovadnevaite et al., 2011), or a population of transformed and aged hydrophobic particles without the gel (Leck et al., 2002; Martin et al., 2011), as described in Leck and Bigg (2005a).

Polymer microgels are quite ubiquitous in the world's oceans and are a component of high molecular weight (HMW) dissolved organic matter (DOM) or, more specifically, colloidal-sized organic matter. About $30-50 \%$ of DOM in surface waters can exist in the colloidal phase, much of which (30\% of HMW DOM) is composed of biological reactive polysaccharides (Benner et al., 1992). The macromolecular polysaccharides are mostly characterized by a distinctive distribution of neutral sugars, including hexose, pentose and deoxy sugars. Acidic polysaccharides, containing sulfate ester or uronic acid, are also very often found in the polymeric materials (Mopper et al., 1995; Zhou et al., 1998). The polysaccharides are largely produced as a result of cell exudation during phytoplankton blooms and very often in response to nutrient depletion at the end of blooms (Mopper et al., 1995). Krembs et al. (2002) have, in addition, shown that Arctic sea ice diatoms release substantial quantities of extracellular polysaccharides as an effective buffering and cryoprotectant against extreme environmental conditions (low temperature and high salinity).

The assembly of free organic macromolecules into microgels is a dynamic process in which macromolecules continuously redistribute themselves between bulk seawater and assembled microgels having a broad range of sizes (Verdugo et al., 2004), ranging from a few nanometers to several micrometers in diameter, the latter sometimes known as transparent expolymeric particles (TEP) (Passow, 2002). Selfassembled polymer gels disperse under the influence of ultraviolet light (Orellana and Verdugo, 2003) and undergo volume phase transition upon acidification (Chin et al., 1998).
Given that surface active polysaccharides can act as effective interbridges of coagulation, they can facilitate particle aggregation, which in turn accelerate the export of sinking particles to the deep ocean (Verdugo et al., 2004). The important implications for the biogeochemical cycle of carbon have long been of interest and widely studied. However, the processes causing accumulation of biopolymers within the SML and their upward flux into the air above are largely unknown.

In this study, we determined the composition of the dissolved organic matter with emphasis on polysaccharides in the high Arctic open lead SML and subsurface waters (SSW) during summer, the most biologically active period, and into the autumn freeze up. We present novel measurements of molecular composition of size-fractionated polysaccharides in both SML and SSW. To assess the dynamic processes occurring both at the SSW-SML and at the air-SML inter-phase, experimental studies of accumulation of surfaceactive polysaccharides were performed by bubble adsorption experiments. The monosaccharide composition of bubble bursting-generated aerosol particles was compared to that of seawater HMW DOM. As an implication for the CCN-cloud relationship, a possible transfer pathway of the surface-active microcolloidal matter into the atmosphere is discussed.

\section{Route of the expedition and measurement systems}

\subsection{Route of the expedition}

The marine samples were collected during an expedition on the Swedish icebreaker R/V Oden to the central Arctic Ocean in the summer of 2008 (ASCOS-2008). ASCOS combined meteorology, atmospheric chemistry and physics, marine biology and chemistry, as well as physical oceanography to understand the processes controlling the formation of lowlevel clouds. Further logistical details can be found elsewhere (Paatero et al., 2009).

The majority of the marine biology and chemistry measurements commenced when the ship was moored to an ice floe, which drifted passively within the pack ice (PI). Sampling was conducted from 12 August 2008 (Day of Year (DOY) 225 ) at $87.3^{\circ} \mathrm{N}, 1.5^{\circ} \mathrm{W}$ until 2 September (DOY 246) at $87.1^{\circ} \mathrm{N}, 12^{\circ} \mathrm{W}$. Additional subsurface seawater samples were collected outside the PI: namely two open water (OW) stations (DOY $216,78.2^{\circ} \mathrm{N}, 7.5^{\circ} \mathrm{E}$; DOY $252,78.9^{\circ} \mathrm{N}$, $9.2^{\circ} \mathrm{E}$ ) and two marginal ice zone (MIZ) stations (DOY 217 $8,79.9^{\circ} \mathrm{N}, 6.1^{\circ} \mathrm{E}$; DOY $\left.251-2,80.3^{\circ} \mathrm{N}, 9.7^{\circ} \mathrm{E}\right)$. The full extent of the expedition is shown in Fig. 1a. Figure 1b shows a photograph of the ice floe ( 3 by $6 \mathrm{~km}$ in size). The open lead station, about $3 \mathrm{~km}$ away from R/V Oden, was an open water channel within the drifting ice floes. The size and shape of the lead was dynamic, opening and closing from day to day, following the drifting ice, with approximately $2 \mathrm{~km}$ in length and $20 \mathrm{~m}$ to $100 \mathrm{~m}$ in width. Small ice floes floated into the 

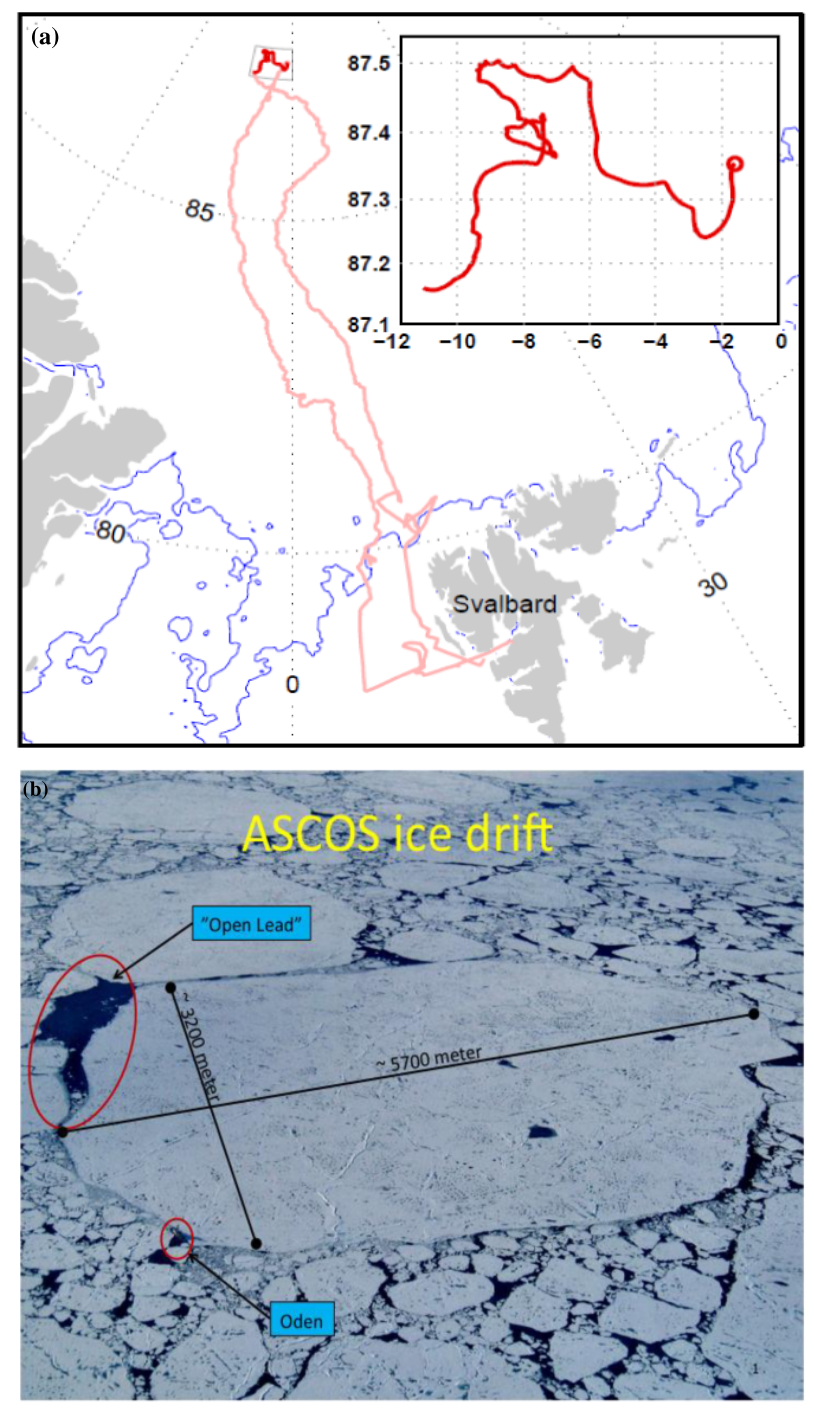

Fig. 1. (a) Map of the ASCOS cruise track (pink) with the ice-drift period highlighted (red, and inset area indicated) and shown in detail (inset, $\sim 87 \mathrm{oN}, \sim 1-11 \mathrm{oW}$ )), with the start of the drift marked by the circle. The ice edge (blue line) is shown for the start of the drift period on 12 August 2008. (b) The ice floe, on which the ASCOS measurements took place, with the icebreaker R/V Oden and the open lead sampling site are indicated.

water channel occasionally. The study site had ice coverage of $\sim 90 \%$ and ice thickness of $\sim 2.5 \mathrm{~m}$, on average, during the sampling period.

\subsection{Sampling at the site of the open lead}

SSW samples were taken from the edge of the lead at a depth of about $0.5 \mathrm{~m}$. SML water was collected from the open lead using two battery-operated, catamaran, radio-controlled vessels (Knulst et al., 2003; Matrai et al., 2008). Each vessel was equipped with a rotating drum covered with a thin sheet of Teflon film etched with a solution of sodium in liquid ammonia to make it hydrophilic. The vessels were navigated randomly across as much of the open lead as possible to get a representative sample. Care was taken to avoid running the collector through its own wake in order to minimize the sample contamination. Microlayer water adhered to the surface of the partially submerged rotating drum and then dripped continually into pre-cleaned, amber, borosilicate glass bottles located inside the skimmer vessel. Operational collecting time varied between $20 \mathrm{~min}$ and $2 \mathrm{~h}$ per run. The thickness of the SML was estimated by dividing the volume of the SML sample collected by the surface area swept by the drum. The lead was at times partly covered by a thin layer of sea ice, when sampling of the SML was suspended (these conditions will be further discussed in Sect. 3.1). The newly formed sea ice was collected in pre-cleaned, polyethylene containers. In addition, the ice algae assemblage loosely attached to the bottom of the ice floe was collected at the edge of open lead. The samples were transported back to the laboratory on R/V Oden packed in snow and ice in dark containers. The fresh ice samples were allowed to melt at $4{ }^{\circ} \mathrm{C}$ overnight before further treatment.

\subsection{Bubble experiments}

Bubble experiments were performed based on a modified method by Mopper et al. (1995) and Keene et al. (2007). In brief, seawater without pre-filtration was fed directly into a pre-cleaned glass tower $\left(15.3 \mathrm{~L}, 2 \mathrm{~m}\right.$ height), held at $4{ }^{\circ} \mathrm{C}$ (room temperature in the ship's lab). Purified zero air was forced into the system through a sintered glass frit (nominal pore size $15-25 \mu \mathrm{m}$ ) from the bottom of the tower. The air flow was controlled at a rate of $150 \mathrm{ml} \mathrm{min}^{-1}$. The chosen frit pore size at the present flow rate enabled a sufficient number of gentle bubbles, with sizes ca. $300 \mu \mathrm{m}$ in diameter, within the range of those measured in the open lead (Norris et al., 2011). Unlike the experiment of Mopper et al. (1995) who aimed to collect surface active foam, the present bubble experiment was designed to investigate the chemical dynamics of polysaccharides in seawater in the presence of rising bubbles. The air flow was thus constantly controlled, rather than being optimized for high foam production. Although the bubble size ( $300 \mu \mathrm{m}$, on average) and concentration in the labscale system might not be representative of those produced at ambient conditions at the open lead (range 30-560 $\mu \mathrm{m}$ ) (Norris et al., 2011), the dynamic behavior of bubble coagulation of surface active materials and the underlying processes are the same, i.e., enrichment of polysaccharides in surface water as well as in the nascent aerosols. The possible discrepancy between properties of natural and laboratory generated bubbles affecting an enhancement of transport of organic matter to SML is further discussed in Sect. 5. After 1$\mathrm{h}$ of bubbling, seawater at the upper most layer (about $3 \mathrm{~cm}$ ) together with foamy substances (if available) were slowly overflowed into a collecting flask by an additional feeding of seawater through the middle of the experimental tower. 
This sample $(200 \mathrm{ml})$ is referred to as the "foam layer" in the following text, and the non-bubbled background water (before bubbling) and bubble-stripped seawater after each experiment are referred to as "reference" and "residual seawater", respectively. Water droplets sprayed by bursting bubbles were collected with a pre-combusted glass plate (acting as an impact surface) at $\sim 10 \mathrm{~cm}$ height above the liquid level. The particles on the glass plate were then carefully rinsed with ultrapurified (Milli-Q) water into a pre-cleaned polycarbonate tube and frozen $\left(-80^{\circ} \mathrm{C}\right)$ aboard, before further sample preparation.

\subsection{Determination of total organic carbon, bulk carbohydrate and associated organic parameters}

Total organic carbon (TOC) samples were collected in acidcleaned containers and stored frozen, until analysis by high temperature combustion (Knap et al., 1996). Particulate organic carbon and nitrogen (POC and PON) were quantified in material collected on Whatman GF/F glass fiber filters stored frozen until laboratory analysis (Knap et al., 1996). Dissolved organic carbon (DOC) was calculated by subtracting POC from the TOC (Sharp, 2002). Bulk carbohydrates in free (= monosaccharides) and combined (= polysaccharides) form (d-MCHO and d-PCHO) were quantified with the spectrophotometric TPTZ (tripyridyl-s-triazine) protocol (Hung et al., 2003, 2001). Individual dissolved free amino acids (DFAA) were determined on $0.2 \mu \mathrm{m}$-filtered samples, with acid hydrolysis and separation achieved by using reverse phase high performance liquid chromatography with precolumn OPA derivatization (Mopper and Dawson, 1986; Keil and Kirchman, 1991). Proteins were determined in the particulate phase (Clayton et al., 1988; Dortch et al., 1984). Chlorophyll $a$ (chl $a$ ) was determined according to HolmHansen et al. (1965). Phytoplankton and bacterioplankton were enumerated with flow cytometry (Sieracki et al., 1999), after fixation with $0.5 \%$ paraformaldehyde, flash-freezing in liquid nitrogen, and storage at $-80^{\circ} \mathrm{C}$.

\subsection{Ultrafiltration}

Ultrafiltration of SSW and SML samples was performed onboard ship, based on the method by Gao et al. (2010). Samples were first filtered under mild pressure through a polycarbonate membrane (nominal pore size $0.22 \mu \mathrm{m}$ in diameter) to collect particulate organic matter (POM, $>0.22 \mu \mathrm{m}$ in diameter). The algal assemblage was filtered through a nylon sheet of $20 \mu \mathrm{m}$ mesh. The filtered samples were then ultrafiltered and diafiltered through a tangential flow filtration system (TFF, Millipore) equipped with cartridges with molecular weight cut off (MWCO) at $5 \mathrm{kDa}$. The fraction that passed through the $0.22 \mu \mathrm{m}$ filters but was retained by TFF is referred to as HMW DOM. Note that the HMW DOM fraction falls in the size range between $5 \mathrm{kDa}$ (equivalent to particle size of $5 \mathrm{~nm}$ ) and $0.22 \mu \mathrm{m}$ and, therefore, is considered as microcolloidal in size (Leck and Bigg, 2010; Wells and Goldberg, 1991). Dissolved free monosaccharides with low molecular weight cannot be retained by TFF and thus are not included in the subsequent analysis. Dialysis tubing $(5 \mathrm{kDa}$ MWCO, Pierce) was used as an alternative method to isolate and desalt samples with small volume (i.e., foam layer samples) (Gao et al., 2010; Underwood et al., 2010). After ultrafiltration, the samples were stored frozen at $-80^{\circ} \mathrm{C}$ until laboratory analysis. Details about the ultrafiltration method are summarized in Table 1. It should be stressed that the fraction of DOM collected resides in the operationally defined dissolved phase. The separation of the particulate and dissolved phase has historically been accomplished by filtration, rather than obtained by solubility (Hansell and Carlson, 2002). In fact, the organic matter in the DOM fraction comprises both colloidal material or particles (water insoluble), viruses, and a truly dissolved organic carbon pool (Verdugo et al., 2004).

\subsection{Determination of monosaccharide composition using liquid chromatography coupled with tandem mass spectrometry (LC/MS/MS)}

Monosaccharides present in a combined form (polysaccharides) were determined according to the method by Gao et al. (2011). In brief, vacuum- dried samples were hydrolysed with $4 \mathrm{M}$ trifluoroacetic acid (TFA) at $100^{\circ} \mathrm{C}$ for $2 \mathrm{~h}$. Excess TFA was removed by vacuum evaporation, and the hydrolysate was further cleaned by solid phase extraction. The hydrolysate was reconstituted in acetonitrile and water ( $80: 20, \mathrm{v} / \mathrm{v})$ prior to analysis with LC/MS/MS. TFA hydrolysis is a relative mild method compared to the strong sulfuric acid method that is often used for carbohydrate studies in seawater (Panagiotopoulos and Sempere, 2005) focusing on "refractory" structural polysaccharides or terrestrial celluloserich polysaccharides (Kerherve et al., 2002; Panagiotopoulos and Sempere, 2005). As a result, the monosaccharides released by TFA are presumed to be freshly produced and largely from extracellular algal secretions. Liquid chromatographic separation was performed using an aminopropylsilica column $(150 \times 2.1 \mathrm{~mm}, 5 \mu \mathrm{m}, \mathrm{ZORBAX} \mathrm{NH} 2$, Agilent $)$ at room temperature, with an LC system coupled to a triple quadrupole mass spectrometer, equipped with a heated electrospray ionization probe (Gao et al., 2011).

The glucose and mannose could not be baseline-separated and were determined together using one peak since the response factor for these two monosaccharides was equal when injected separately. The monosaccharides obtained by the LC/MS/MS analysis described above are also referred to as neutral sugars (NS), and the sum of the individual NS is referred herein as total hydrolysable neutral sugars (THNS). The THNS concentration in carbon units ( $\mu \mathrm{MC}$ ) for the calculation of the NS yield was obtained by multiplying the concentration of pentose by 5 and all other monosaccharides by 6 (Skoog et al., 2008). The monosaccharide concentrations were blank-corrected. 
Table 1. Different fractions of organic matter obtained by ultrafiltration.

\begin{tabular}{|c|c|c|}
\hline Organic components & Filtration technique & Size range of organic matter \\
\hline Particulate organic matter (POM) & $\begin{array}{l}\text { Microfiltration through } \\
\text { polycarbonate membrane }\end{array}$ & $>0.22 \mu \mathrm{m}$ \\
\hline $\begin{array}{l}\text { High molecular weight (HMW) } \\
\text { Dissolved organic matter (DOM) } \\
\text { (also referred to as microcolloids } \\
\text { or microgels) }\end{array}$ & $\begin{array}{l}\text { Ultrafiltration using TFF system } \\
\text { or dialysis tube when the sample } \\
\text { volume is low }\end{array}$ & $5 \mathrm{kDa}$ to $0.22 \mu \mathrm{m}$ \\
\hline $\begin{array}{l}\text { Low molecular weight (LMW) } \\
\text { DOM (including dissolved free } \\
\text { monosaccharides) }\end{array}$ & $\begin{array}{l}\text { The fraction that passed through } \\
\text { TFF system }\end{array}$ & $<5 \mathrm{kDa}$ \\
\hline
\end{tabular}

\subsection{Statistical analysis}

Statistical analyses were performed using Statistica 7.0 (StatSoft Inc.) statistical packages. Non-parametric Spearman's rank correlation $(R)$ was used to compare the correlation of non-normally distributed variables. Difference and correlation were considered to be significant at $p<0.05$ (95\% confidence level). One-way analysis of variance (ANOVA) was used to test for significant difference between the results of individual groups, and difference was considered to be significant when the F-value was greater than the cut-off value in an F-table.

\section{Dissolved organic matter and carbohydrates in the SSW and SML}

\subsection{Factors influencing the biological activity at the open lead site}

The abundance, molecular size, chemical composition and reactivity of DOM vary considerably as a function of the level of biological activity in the SML and the underlying SSW (upper ca. $20 \mathrm{~m}$ within the euphotic zone) (Matrai et al., 2008). Within these layers, biological activity is influenced by such factors as depth of the surface mixed layer and stratification below it, the formation of melt pools and the removal of dry snow in summer, which greatly increase the available radiation at a given depth in the sea (English, 1961) as well as temperature and nutrient concentration. In order to discuss the observed changes in concentrations of the dissolved organic matter in the water, it is therefore necessary to consider how such physical parameters varied during the ice drift and how they influenced biological activity.

The sun was consistently above the horizon for the duration of ASCOS. Surface air temperature varied substantially from near $0^{\circ} \mathrm{C}$ to $-12^{\circ} \mathrm{C}$. Based on the analyses of the surface energy budget, the drift was divided into four distinct periods (Sedlar et al., 2011), shown in Fig. 2. The first period was typical of the pack ice melt season, having numerous melt ponds on the ice surface, with temperatures around $0^{\circ} \mathrm{C}$ from DOY 226 to DOY 233. A weather system at the end of the 1st period, during 20 August (DOY 233), marked the end of the melt season and was followed by the 2 nd period with a drop in temperature to $\sim-6^{\circ} \mathrm{C}$ for about 2.5 days (DOY 234-DOY 237). The conditions in the $3 \mathrm{rd}$ period were governed by a persistent stratocumulus layer that contributed to maintain the surface energy balance close to zero through surface cloud-radiative forcing (Sedlar et al., 2011). Temperatures ranged between -2 and $-3{ }^{\circ} \mathrm{C}$. As a consequence, the actual transition to the autumn freeze-up was temporarily postponed until the end of the 3th period (DOY 243). The 4th period started on 31 August (DOY 244) as the persistent stratocumulus layer went away. This resulted in a negative surface energy budget, with a drastic drop in temperature to $-12{ }^{\circ} \mathrm{C}$.

As a result of the temporal development of the surface energy balance, the lead at the sampling site was completely ice free during the 1 st and the 3 rd periods. In the 2 nd period, freezing of melt ponds occurred, along with heavy riming and frost deposits onto the surface of the frozen ponds. The lead at the sampling site started to freeze on DOY 233 and was covered with a layer of frazil ice until DOY 238 (3rd period) when the lead opened up exposing open water again. The melt ponds recovered but were at times covered with a thin layer of dry snow. On DOY 245 (4th period), a freezeup of surface water at the open lead site was observed. The period during the ice-drift spans the transition period from the end of the summer melting to the onset of the autumn freeze-up.

The formation of a highly stable surface mixed layer prevents the transport of phytoplankton to depths where their growth is light limited (generally below 30-50 m, Olli et al., 2007; Sverdrup, 1953) and is therefore a factor important to biological activity. In polar seas, its formation is dominated by melting and freezing with the consequent variations in the relative density of sea water. During ASCOS, the wellmixed upper layer was about $28 \mathrm{~m}$ in depth with little variation in terms of either temperature (ranging between -1.73 and $-1.68^{\circ} \mathrm{C}$ ) or salinity (32 psu) (Sirevaag et al., 2011). The relatively low density of the surface mixed layer in summer is due partly to runoff of melt waters of low salinity (1-4 psu) 

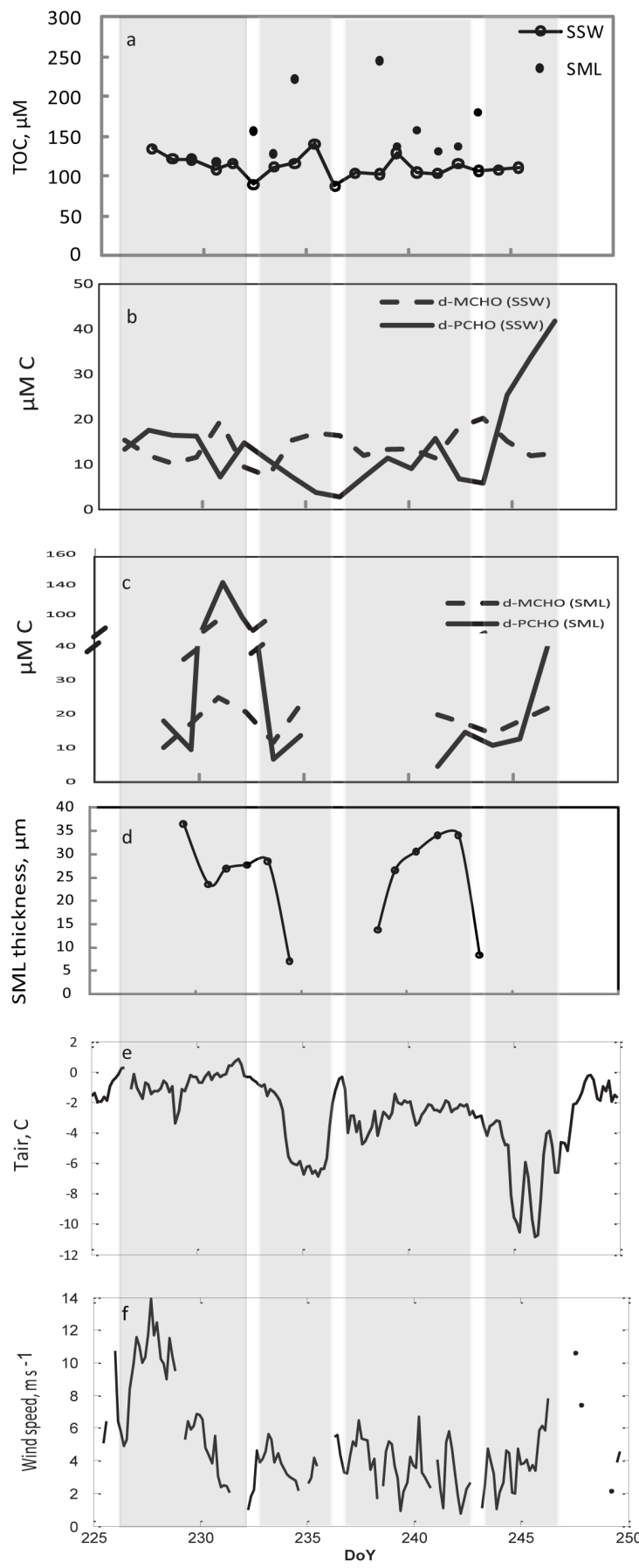

Fig. 2. Time series of total organic carbon (TOC) in surface microlayer (SML) and subsurface water (SSW) (a), dissolved monosaccharides (d-MCHO) and dissolved polysaccharides (dPCHO) in subsurface water (SSW) (b), dissolved monosaccharides (d-MCHO) and dissolved polysaccharides (d-PCHO) in surface microlayer (SML) (c), SML thickness (d) and air temperature (e). The four distinct periods based on the analyses by Sedlar et al. (2011) of the surface energy budget (see Sect. 3.1) are indicated by gray panels. into the open leads and partly due to continental runoff of fresh water from Siberian and other rivers.

Moreover, wind contributes to processes occurring right at the air-sea interface, which might lead to the concentrations of DOM varying both temporally and spatially with thickness of the SML. Disruption of the SML at high wind speed has been well documented (Williams et al., 1986; Wurl et al., 2009), while a highly "dense" SML and pronounced loading of organic particles have been reported under calm weather conditions (Stolle et al., 2010). Such negative relationship between the SML thickness and wind speed has also been documented in the Arctic open leads during a past expedition to the same area and time of year (Knulst et al., 2003). During ASCOS, near-surface winds were most often in the 2-6 $\mathrm{ms}^{-1}$ range and seldom $>10 \mathrm{~ms}^{-1}$ (Fig. 2f). Under these typical low wind conditions inside the pack ice, the thickness of SML varied from day to day from 7.7 to $36.5 \mu \mathrm{m}$ (Fig. 2d). The 1st period that saw the highest winds along with the passage of a large number of frontal systems had no data of SML thickness collected.

The increasing light and the formation of a stable mixed layer during melting of the pack ice (maximum in the month of August) favor phytoplankton growth and nutrient consumption, which can be partially replenished by the release of winter brine. Moreover, the ice itself is a source of microalgae, which can be released into the mixed layer during melting (Smith and Nelson, 1985). The pack ice phytoplankton community during the summer season has been reported to be dominated by flagellates and other picoplankton cells (Matrai et al., 2008). At the lead sampling site, the chl $a$ concentrations (proxy for phytoplankton biomass) varied between 0.4 and $2.3 \mu \mathrm{g} 1^{-1}$ during the ice drift, consistent with numbers reported by Leck and Persson (1996). Total abundances of phytoplankton and bacteria ranged from 263 to 811 cells ml $^{-1}$ and $2.11 \times 10^{5}$ to $3.66 \times 10^{5}$ cells ml $^{-1}$, respectively, and were comparable to previous reports from Arctic open leads (Matrai et al., 2008; Olli et al., 2007). Past measurements in the same area have reported on a mesozooplankton community that was dominated by small copepods, contributing more than $90 \%$ of the total mesozooplankton biomass (Olli et al., 2007). No numbers on zooplankton were available during this study.

\subsection{Organic matter in the open lead SSW}

General characteristics of organic matter in the SSW of the open lead are presented in Table 2. The concentration of TOC measured during the ice drift was relatively invariant over the 4 periods, with a mean value of $112.2 \pm 13.4 \mu \mathrm{MC}$. Slightly elevated numbers $(140.8 \mu \mathrm{MC})$ were observed in conjunction with the drop in temperature during the 2nd period (Fig. 2e). The observed TOC concentration at the open lead site was relatively high compared to the global average (60$90 \mu \mathrm{MC}$ ) (Hansell and Carlson, 2002) but in agreement with previous reports from the central Arctic Ocean (Amon and 
Table 2. Concentrations of particulate organic carbon (POC), total organic carbon (TOC), dissolved bulk free and combined carbohydrate (d-MCHO, d-PCHO), dissolved free amino acid (DFAA) and particulate protein in subsurface seawater of the open lead. The conditions observed at the lead site during each sampling day are indicated.

\begin{tabular}{|c|c|c|c|c|c|c|c|}
\hline Sampling date & Condition of lead & $\begin{array}{r}\text { TOC } \\
(\mu \mathrm{M} \mathrm{C})\end{array}$ & $\begin{array}{c}\text { POC* }^{*} \\
(\mu \mathrm{MC})\end{array}$ & $\begin{array}{r}\mathrm{d}-\mathrm{MCHO} \\
(\mu \mathrm{MC})\end{array}$ & $\begin{array}{r}\text { d-PCHO } \\
(\mu \mathrm{MC})\end{array}$ & $\begin{array}{r}\text { DFAA } \\
(\mathrm{nM})\end{array}$ & $\begin{array}{l}\text { Protein } \\
\left(\mathrm{mg} \mathrm{l}^{-1}\right)\end{array}$ \\
\hline 14 Aug (JD 227.46) & Open & 134.3 & $8.2(6.1)$ & 15.4 & 13.4 & 2791.0 & 0.03 \\
\hline 15 Aug (JD 228.46) & Open & 121.6 & - & 12.0 & 17.6 & - & 0.04 \\
\hline 16 Aug (JD 229.42) & Open & 120.8 & $10.2(8.4)$ & 10.2 & 16.5 & 2530.3 & 0.02 \\
\hline 17 Aug (JD 230.60) & Open & 108.6 & - & 11.6 & 16.3 & - & 0.04 \\
\hline 18 Aug (JD 231.44) & Open & 116.1 & - & 19.6 & 7.3 & 1592.8 & 0.03 \\
\hline 19 Aug (JD 232.42) & Open & 89.8 & - & 9.4 & 14.8 & - & 0.03 \\
\hline 20 Aug (JD 233.42) & Started to freeze & 111.1 & $5.7(5.1)$ & 7.4 & 11.0 & 2231.1 & 0.04 \\
\hline 21 Aug (JD 234.44) & Started to freeze & 116.1 & - & 15.4 & 7.3 & - & 0.04 \\
\hline 22 Aug (JD 235.42) & Covered with frazil ice layer & 140.8 & $12.6(8.9)$ & 16.9 & 3.8 & 2594.4 & 0.04 \\
\hline 23 Aug (JD 236.42) & Covered with frazil ice layer & 87.8 & - & 16.4 & 2.8 & - & 0.03 \\
\hline 24 Aug (JD 237.42) & Covered with frazil ice layer & 104.1 & - & 12.0 & 7.2 & - & 0.03 \\
\hline 25 Aug (JD 238.61) & Open up again & 102.8 & - & 13.4 & 11.4 & - & 0.03 \\
\hline 26 Aug (JD 239.44) & Open & 128.8 & - & 13.5 & 9.1 & 2531.4 & 0.01 \\
\hline 27 Aug (JD 240.44) & Open & 104.8 & - & 11.4 & 15.8 & - & 0.02 \\
\hline 28 Aug (JD 241.46) & Open & 103.4 & $6.9(6.7)$ & 18.3 & 6.8 & 1381.4 & 0.02 \\
\hline 29 Aug (JD 242.44) & Open & 115.7 & - & 20.2 & 5.9 & - & 0.03 \\
\hline 30 Aug (JD 243.44) & Open & 106.9 & - & 15.2 & 25.4 & 1117.4 & 0.03 \\
\hline 31 Aug (JD 244.44) & Start to freeze up & 108.3 & - & 11.9 & 33.8 & - & 0.04 \\
\hline $1 \mathrm{Sep}$ (JD 245.42) & Closed persistently & 110.9 & $16.5(14.9)$ & 12.5 & 41.8 & 701.5 & 0.03 \\
\hline
\end{tabular}

* The percentage of POC in TOC is indicated in parentheses.

Benner, 2003; Rich et al., 1997). The latter studies suggested that elevated Arctic TOC levels should be viewed as a result of the presence of autochthonous production dominated by sea ice algae, microbial decomposition and mesozooplankton grazing. The high concentration of TOC could also be related to the generally shallow euphotic zone $(<20 \mathrm{~m})$ (Leck and Persson, 1996; Olli et al., 2007), where most of primary production has been reported to take place (Olli et al., 2007). The DOC fraction represented the major pool of the TOC, accounting for $91 \pm 1 \%$, with the remaining fraction made up by POC. The concentrations of POC were significantly correlated with concentrations of PON (Spearman rank correlation coefficient $R=0.999$ ). This suggests that these constituents are associated with a common macromolecular structure. There was also a significant correlation between POC and chl $a(R=0.886)$ indicating that ice algae and phytoplankton populations were among the primary factors controlling the abundance of POC at the open lead site during the extent of the drift. The average atomic $\mathrm{C}: \mathrm{N}$ ratio was $9.4 \pm 1.0$, higher than the global Redfield ratio of phytoplankton (C:N:P, 106:16:1, C:N ratio $=6.6)$ but closer to values reported for the Arctic Ocean (Olli et al., 2007), supporting a microalgal origin of the particulate organic matter (Redfield et al., 1963).

\subsection{Dissolved carbohydrates in the open lead SSW}

Carbohydrate is a generic term for polyhydroxycarbonyl compounds consisting of a multiplicity of substances including HMW (high molecular weight) polysaccharides and their constituting monomers released via enzymatic hydrolysis. The bulk determination of the colorimetric method in this study is defined as "total carbohydrates", while the monomeric sugars detected by the LC/MS/MS are referred to as "neutral sugars" (NS). Carbohydrates, such as algal and bacterial exudates, are mainly combined polysaccharides providing the major proportion of dissolved carbohydrates. Monosaccharides, or carbohydrate in free form (d-MCHO), can be utilized heterotrophically and are less abundant compared to combined carbohydrate (polysaccharides, d-PCHO).

During the ice drift, total dissolved carbohydrates, including both free (d-MCHO) and combined (d-PCHO) form, accounted for $22 \pm 4 \%$ of the TOC pool (Table 2), similar to lower latitude open oceans (McCarthy et al., 1996; Pakulski and Benner, 1994). The temporal evolution of free and combined carbohydrate in SSW during the ice drift is shown in Fig. 2b. Concentration of d-PCHO varied by a factor of two during the first period of the drift, ranging from 7.3 to 17.6 $\mu \mathrm{MC}$ C. On DOY 236, during the 2nd period (open lead site covered with a layer of frazil ice), concentrations decreased to $2.8 \mu \mathrm{MC}$, but increased thereafter substantially, up to $41.8 \mu \mathrm{MC}$, until the surface water started to freeze up again during the last regime (DOY 243 to DOY 245). 
Previous studies (Brierley and Thomas, 2002; Krembs et al., 2002; Krembs and Deming, 2008) have shown that secretion of EPS by microorganisms might be enhanced in response to the extreme environmental conditions within a lead (e.g., low temperature and high salinity), which in turn would lead to a high carbohydrate loading. The observed high contributions of d-PCHO observed during the 4th regime could therefore be due to enhanced secretion of EPS at low temperature. In comparison, the variation of SSW d-MCHO levels during the drift was not significant. The observed negative correlation $(R=-0.621)$ between $\mathrm{d}-\mathrm{MCHO}$ and d-PCHO suggested that the former could be derived in part from the degradation of the latter. The transformation of carbohydrate between the free and combined forms is governed by both physical and biological processes. Carbohydrates in the dissolved phase, particularly those with high molecular weight, can aggregate abiotically to form highly polymerized polysaccharides, known as gels, as part of a reversible physical process (Chin et al., 1998). Conversely, larger aggregates such as TEP can be converted back into the dissolved pool biotically via, e.g., enzymatic hydrolysis by heterotrophic bacteria (Decho, 1990). However, there was no apparent temporal correlation between DOC and carbohydrate concentrations. One suggested explanation is that the concentration of dissolved carbohydrates is related not only to phytoplankton and ice algae growth, but also to bacterial and microzooplankton activity (Deming, 2010; Rich et al., 1997; Verity et al., 1999), both of which can vary over time.

\subsection{Enrichment of organic matter (particulate and dissolved) and dissolved carbohydrates in SML}

There is a continuous exchange of organic matter (chemical composition and concentration) between the SSW and SML (Liss and Duce, 1997). Bigg and Leck (2008) proposed a bubble-induced mechanism responsible for transporting organic-rich material towards the SML. It was suggested that the highly surface active polymers can readily attach to the surface of rising bubbles and self-collide to form larger aggregates that may embed solid particles such as bacteria, phytoplankton and their detritus. On the other hand, it has been suggested that the process of polymerization into larger aggregates can inhibit the enrichment of DOM in the SML, including carbohydrate and amino acid (Wurl and Holmes, 2008). Furthermore, temperate water observations indicate that the higher the initial concentration of organic compounds in SSW, the relative lower enrichment of the matter in the SML will result (Williams et al., 1986). It is also well known that the exopolymers can help the downward transport of biological and chemical components into the deep ocean, in particular POC including bacteria and phytoplankton (Wassmann and Reigstad, 2011). However, the flux of vertical downward export of organic carbon (by sinking, aggregation and coagulation) has been reported as low under the Arctic pack ice (Olli et al., 2007).
Unlike the SSW, there was no negative correlation between d-MCHO and d-PCHO observed in the SML $(r=0.321, p<0.05)$ (Fig. 2c), suggesting a passive accumulation of organic materials (Matrai et al., 2008). Table 3 presents enrichment factors (EF), defined as the ratio of the concentration in the SML over that in SSW. TOC was slightly enriched (mean EF value of $1.5 \pm 0.4$ ) in the SML. A slight SML depletion (indicated by $\mathrm{EF}<1$ ) was occasionally observed for d-MCHO, d-PCHO, dissolved free amino acids (DFAA) and proteins. A significant enrichment of d-PCHO $(\mathrm{EF}=19.4)$ and proteins $(\mathrm{EF}=14.3)$ was recorded during DOY 231.44 (1st period), whereas d-MCHO and DFAA were only slightly enriched with EF of 1.3 and 2.3, respectively. The EF of TOC in this study is similar to observations in the North Pacific (Henrichs and Williams, 1985) and Singapore Strait (Wurl and Holmes, 2008).

It is difficult to compare the accumulation of organic material within the SML using only EF when the thickness of the SML varied substantially, as displayed in Fig. 2d. This is because the EF value will depend on the thickness of the specific SML collected (Liss and Duce, 1997). Excess concentration is thus often used as it normalizes for SML thickness (Liss and Duce, 1997; Matrai et al., 2008) by defining it as the difference between the SML and SSW concentrations, multiplied by the thickness of the SML. The SML excess concentrations for observed organic parameters (Table 4) confirm the enrichment patterns during most of sampling days. During the ice drift, Norris et al. (2011) revealed that the number concentration of bubbles correlated positively to the heat flux from sea to air. The high number concentrations of bubbles during DOY 232 (1st period) and DOY 240 (3rd period) corresponded to the relatively high SML excess concentrations of TOC, confirming a physical transport process. Furthermore, the strong enrichment of polysaccharides and proteins (Table 3), as opposed to the "truly" dissolved pools (e.g., monosaccharides and amino acids) observed on DOY 231, supports the selective ascending of organic compounds under the prevailing environmental conditions.

\section{Extracellular polysaccharides in the SSW and SML}

Extremely numerous and variable numbers of microcolloid particles (ranging between $10^{6}$ and $10^{14} \mathrm{ml}^{-1}$ ) have been observed in the SML of open leads of the high Arctic during the month of August (Bigg et al., 2004). Particle size distributions were also very variable with modal diameter sizes of $10 \mathrm{~nm}$ in some samples and $40-50 \mathrm{~nm}$ in others, with the $40-50 \mathrm{~nm}$ particles appearing to be aggregates of the $10 \mathrm{~nm}$ ones. The variability of the observed size distributions may be a consequence of different stages of assembly and/or aggregation discussed in the introduction. Orellana et al. (2011) showed that marine polymer microgels from the open lead sampling site underwent reversible phase transition as a function of $\mathrm{pH}$, dimethyl sulfide, and dimethylsulfoniopropionate 
Table 3. Enrichment factor of TOC, d-MCHO, d-PCHO, DFAA and particulate protein in the surface microlayer.

\begin{tabular}{lrrrrr}
\hline Sampling date & TOC & d-MCHO & d-PCHO & DFAA & Protein \\
\hline 16 Aug (DoY 229.42) & 1.0 & 1.0 & 1.1 & 0.5 & 0.7 \\
17 Aug (DoY 230.60) & 1.1 & 1.5 & 0.6 & - & 0.8 \\
18 Aug (DoY 231.44) & - & 1.3 & 19.4 & 2.3 & 14.3 \\
19 Aug (DoY 232.42) & 1.7 & 2.2 & 4.5 & - & 4.0 \\
20 Aug (DoY 233.42) & 1.2 & 1.6 & 0.6 & 0.7 & 1.4 \\
21 Aug (DoY 234.44) & 1.9 & 1.5 & 1.9 & - & 2.0 \\
25 Aug (DoY 238.61) & 2.4 & - & - & - & - \\
26 Aug (DoY 239.44) & 1.1 & 1.5 & 0.5 & 0.6 & 6.1 \\
27 Aug (DoY 240.44) & 1.5 & 1.5 & 0.9 & - & 3.0 \\
28 Aug (DoY 241.46) & 1.3 & 0.8 & 1.6 & 1.35 & 0.9 \\
29 Aug (DoY 242.44) & 1.2 & 0.9 & 2.2 & - & 1.8 \\
30 Aug (DoY 243.44) & 1.7 & 1.4 & 1.6 & 1.74 & 4.1 \\
\hline
\end{tabular}

concentration, which stimulated the gels to attain sizes below $1 \mu \mathrm{m}$ in diameter. Their results showed that polymeric material from the SML and SSW assembled spontaneously into gels that ranged from colloidal to micrometer sizes, similar to polymer gels from other water sources (Orellana and Verdugo, 2003).

\subsection{Enrichment of extracellular polysaccharides in the SML}

THNS concentrations in the SSW of the open lead sampling site (see Table 5) were generally higher in the HMW DOM pool $(94.9 \pm 37.5 \mathrm{nM})$ than in the POM pool $(64.4 \pm 14.5 \mathrm{nM})$ $\left(F_{1.8}=2.88, p=0.128\right)$. Enrichment of THNS in the SML appeared to be a common feature with EFs ranging from 1.7 to 7.0 for particulate polysaccharides and 3.5 to 12.1 for polysaccharides in the HMW DOM (Fig. 3a). This pattern was consistent for all HMW DOM and POM paired samples examined $\left(F_{1.6}=2.93, p=0.138\right)$. The excess concentration of neutral sugars in SML shows a similar pattern to that of EF (Fig. 3b). The higher substantial enrichment of polysaccharides in the HMW DOM class in our measurements indicates that colloidal organic matter could be preferentially scavenged into SML with respect to the POM pool. As discussed above, transmission electron microscopic images of micron-sized particles collected at the same location and season (Bigg et al., 2004) showed that the most abundant components were discrete amorphous aggregates in the modal diameter of about $50 \mathrm{~nm}$. The suspended small colloidal particles in seawater might ascend preferably towards the sea surface through positive buoyancy due partly to low density $\left(0.7-0.8 \mathrm{~g} \mathrm{~cm}^{-3}\right.$ ) relative to seawater (Azetsu-Scott and Passow, 2004), through bubble adsorption as previously mentioned, or as part of the freezing cycle.

Indeed, the high SML EF of THNS of HMW DOM on DOY 239 coincided with the end of the cold episode. It is possible that new ice crystals floating at sea surface contributed to the high THNS since the freshly formed sea ice sample contained a high concentration of THNS $(2285.5 \mathrm{nM}$
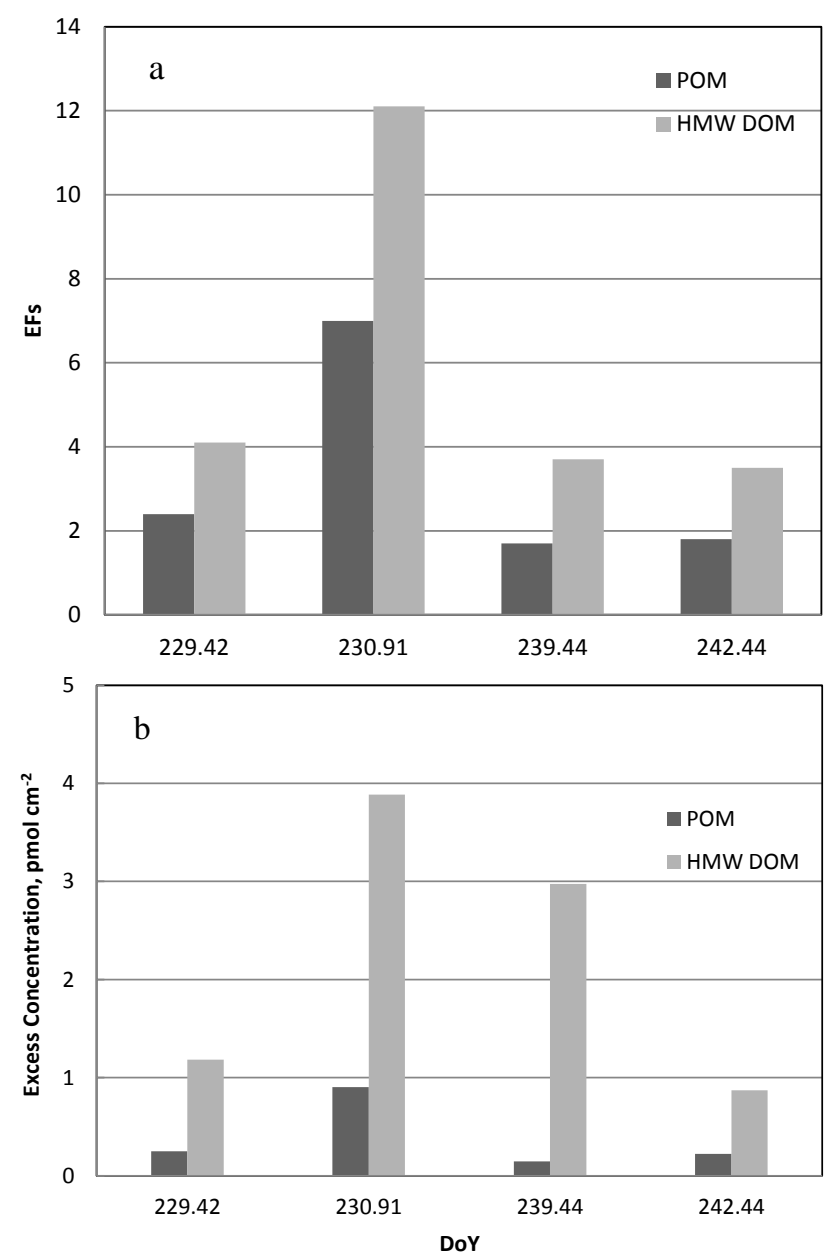

Fig. 3. Enrichment factor (EFs) (a) and excess concentration (b) of total hydrolysable neutral sugars (THNS) in the particulate (POM) and high molecular weight dissolved organic matter (HMW DOM) in the surface microlayer.

in HMW DOM on DOY 234). The high concentration of DOM in sea ice and associated seawater has been reported in a number of studies (Giannelli et al., 2001; Krembs et al., 2002; Krembs and Engel, 2001), most of which attributed to increasing EPS by sea ice diatoms in response to the extreme environmental conditions. Given that the fresh ice was newly formed within one day, it seems unlikely that the EPS observed was produced autochthonously via in situ biological activities. It is further unclear which factors control the DOC or EPS fluxes between the ice and associated brine during the initial freezing. Our study showed that the salinity of the melting sea ice was significant when lower ( $17 \mathrm{psu})$ than the underlying seawater. This implies that the rejection of inorganic sea salts as well as the preferred trapping of organic matter could take place during the initial freezing (Loose et al., 2011; Muller et al., 2011). If the presence of divalent cations $\left(\mathrm{Ca}^{2+}\right.$ and $\left.\mathrm{Mg}^{2+}\right)$ in seawater can act as interbridges to promote the aggregation of DOM (Chin et al., 
Table 4. Surface microlayer (SML) excess concentration of TOC, d-MCHO, d-PCHO, DFAA and particulate protein.

\begin{tabular}{|c|c|c|c|c|c|c|}
\hline Sampling date & $\begin{array}{r}\text { SML thickness } \\
(\mu \mathrm{m})\end{array}$ & $\begin{array}{r}\text { TOC } \\
\left(\mathrm{pmol} \mathrm{cm}^{-2}\right)\end{array}$ & $\begin{array}{r}\mathrm{d}-\mathrm{MCHO} \\
\left(\mathrm{pmol} \mathrm{cm}^{-2}\right)\end{array}$ & $\begin{array}{r}\mathrm{d}-\mathrm{PCHO} \\
\left(\mathrm{pmol} \mathrm{cm}^{-2}\right)\end{array}$ & $\begin{array}{r}\text { DFAA } \\
\left(\mathrm{fmol} \mathrm{cm}^{-2}\right)\end{array}$ & $\begin{array}{r}\text { Protein } \\
\left(\mathrm{ng} \mathrm{cm}^{-2}\right)\end{array}$ \\
\hline 16 Aug (DoY 229.42) & 36.5 & 0.9 & -0.6 & 5.2 & -4.9 & -0.03 \\
\hline 17 Aug (DoY 230.60) & 23.5 & 22.3 & 13.1 & -16.0 & - & -0.02 \\
\hline 18 Aug (DoY 231.44) & 26.9 & - & 14.0 & 358.3 & 5.7 & 1.00 \\
\hline 19 Aug (DoY 232.42) & 27.7 & 184.9 & 30.8 & 142.1 & - & 0.3 \\
\hline 20 Aug (DoY 233.42) & 28.5 & 48.2 & 12.0 & -12.4 & -1.6 & 0.04 \\
\hline 21 Aug (DoY 234.44) & 7.7 & 75.0 & 5.3 & 4.5 & - & 0.03 \\
\hline 25 Aug (DoY 238.61) & 13.8 & 192.9 & - & - & - & - \\
\hline 26 Aug (DoY 239.44) & 26.6 & 21.7 & 16.6 & -12.2 & -3.1 & 0.1 \\
\hline 27 Aug (DoY 240.44) & 30.6 & 163.7 & 17.7 & -3.7 & - & 0.1 \\
\hline 28 Aug (DoY 241.46) & 34.0 & 94.9 & -14.0 & 13.2 & 1.7 & - \\
\hline 29 Aug (DoY 242.44) & 34.1 & 72.5 & -8.0 & 23.0 & - & 0.09 \\
\hline 30 Aug (DoY 243.44) & 8.4 & 62.0 & 5.5 & 12.0 & 0.7 & 0.08 \\
\hline
\end{tabular}

1998), polymeric aggregates bound by inadequate cationic complex and hydrogen bonding due to brine rejection might dissociate more easily during the melting and refreezing processes.

Previous studies of THNS concentration of DOM in central Arctic polar region are limited. The report of Rich et al. (1997) from the ice-covered areas of the Canadian and Eurasian Basins has showed that THNS ranged from 34 to $700 \mathrm{nM}$ for surface unfractionated DOM. Compared to other studies from Arctic Ocean including Greenland Sea (1.05-4.09 $\mu \mathrm{MC}$, equivalent to $170-700 \mathrm{nM}$ ) and the Arctic Mediterranean Sea (75-409 nM) (Engbrodt and Kattner, 2005; Amon and Benner, 2003), the THNS concentrations observed in the central Arctic Ocean during ASCOS had a similar range. SML enrichment of carbohydrates has been reported previously, but the numbers have been limited to bulk concentration of carbohydrates using colorimetric methods (Henrichs and Williams, 1985; Williams et al., 1986). Recent studies demonstrated the enhancement of acidic polysaccharides, or Alcian blue-stained TEP, which procedurally ignores all particles less than $0.4 \mu \mathrm{m}$ diameter (Kuznetsova et al., 2005; Wurl et al., 2009). However, no data are available on the enrichment patterns of smaller polymers, with respect to either chemical dynamics or molecular composition of size-fractionated exopolymers. Nevertheless, as in other lower latitudinal oceans (Amon and Benner, 2003; Goldberg et al., 2011; Kaiser and Benner, 2009), the THNS levels in this study constituted only a small fraction of total DOC, although carbohydrates remain one of the largest identified subcomponents of the DOC pool. Yields of neutral sugars (NS), defined as the percentage of C-normalized monosaccharide concentration to TOC, were higher in SML samples $(2.7 \pm 0.3 \%)$ compared to the SSW $(0.7 \pm 0.2 \%)\left(F_{2.5}=50.7\right.$, $p<0.01)$. The NS yield determined in the fresh ice $(2.8 \%)$ was similar to that of SML samples $\left(F_{1.2}=0.53, p=0.839\right)$. NS yields are often used as an index of the freshness and bioreactivity of organic matter (Amon and Benner, 2003;
Skoog et al., 2008). Higher yields indicate more labile DOM and less diagenetic state. The higher NS yields in the SML samples suggested that newly released exopolymers, without substantial degradation, were more favorably scavenged to the SML.

\subsection{Chemical dynamics of molecular composition of extracellular polysaccharides}

The molecular composition of SSW polysaccharides at the open lead site varied slightly from sample to sample for both the HMW DOM and POM fractions (Table 5). In general, glucose + mannose, fucose, and xylose were the predominant monomers, with galactose and rhamnose being less abundant. Together, these 6 monosaccharides made up over $90 \%$ of the total neutral sugars determined. Arabinose was the least abundant compared to the other 6 neutral sugars, indicating a negligible terrestrial influence of organic matter in the Arctic pack ice, open lead reservoir (Cowie and Hedges, 1984). Ribose and an undefined 5-carbon sugar were occasionally detected in small amounts. Ribose is subjected to decomposition during acidic hydrolysis, and thus the result is less reliable. The undefined 5-carbon sugar might be from lyxose, partly as a product of epimerization from xylose formed through the hydrolysis (Cowie and Hedges, 1984). Given the difficulty of quantification as well as their minor contribution to the total NS determined, these two sugars were not included in the calculation of monosaccharide composition. The determined monosaccharide compositions suggested that macromolecular polysaccharides over the Arctic pack ice area are heteropolysaccharides containing different type of monomers. Because of the relatively uniform distribution of monosaccharides from sample to sample, average molar percentages of monosaccharides are used in the following sections to enable a comparison of the contribution of individual monosaccharide between different reservoirs (i.e., SML, ice, foam, bubble-spray aerosol). Seawater samples 
Table 5. Total hydrolysable neutral sugars (THNS) concentration (nM), NS yields (\% TOC) and monosaccharide composition (mol\%) in particulate (POM) and high molecular weight dissolved (HMW DOM) organic matter fractions of lead subsurface and surface microlayer seawater. The monosaccharide abbreviations are Xyl (xylose), Ara (arabinose), Rha (rhamnose), Fuc (fucose), Glu + Man (glucose + mannose), Gal (galactose).

\begin{tabular}{|c|c|c|c|c|c|c|c|c|c|}
\hline \multirow{2}{*}{ Sample } & \multirow{2}{*}{ Size fraction } & \multirow{2}{*}{$\begin{array}{r}\text { THNS } \\
(\mathrm{nM})\end{array}$} & \multirow{2}{*}{$\begin{array}{r}\text { THNS yields* } \\
\text { (\% TOC) }\end{array}$} & \multicolumn{6}{|c|}{ Monosaccharide composition (mol \%) } \\
\hline & & & & Xyl & Ara & Rha & Fuc & Glu+Man & Gal \\
\hline \multicolumn{10}{|l|}{3 Aug (216.37) } \\
\hline \multirow[t]{2}{*}{ Bulk (OW, 8 m) } & POM & 72.8 & 1.5 & 18.1 & 5.4 & 5.8 & 7.0 & 41.1 & 22.6 \\
\hline & HMW DOM & 228.3 & & 19.7 & 10.2 & 5.4 & 3.7 & 48.0 & 12.9 \\
\hline \multicolumn{10}{|l|}{4 Aug (217.52) } \\
\hline \multirow[t]{2}{*}{ Bulk (MIZ, 8 m) } & POM & 134.7 & 3.5 & 12.4 & 3.8 & 5.7 & 7.7 & 46.3 & 24.1 \\
\hline & HMW DOM & 288.5 & & 15.1 & 10.3 & 14.1 & 9.9 & 26.0 & 24.5 \\
\hline \multicolumn{10}{|l|}{$14 \operatorname{Aug}(227.46)$} \\
\hline \multirow[t]{2}{*}{ SSW (Lead) } & POM & 50.3 & 0.5 & 37.4 & 0.9 & 11.3 & 20.1 & 18.5 & 11.8 \\
\hline & HMW DOM & 62.7 & & 41.5 & 1.1 & 7.7 & 30.8 & 14.7 & 4.2 \\
\hline \multicolumn{10}{|l|}{16 Aug (229.42) } \\
\hline \multirow[t]{2}{*}{ SML(Lead) } & POM & 118.0 & 2.5 & 28.4 & 3.8 & 13.5 & 5.8 & 44.8 & 3.7 \\
\hline & HMW DOM & 429.2 & & 41.5 & 0.1 & 2.5 & 212.1 & 32.4 & 1.4 \\
\hline \multirow[t]{2}{*}{ SSW(Lead) } & POM & 49.6 & 0.7 & 24.0 & 1.5 & 12.2 & 6.3 & 44.3 & 11.7 \\
\hline & HMW DOM & 104.7 & & 29.2 & 1.5 & 5.6 & 28.2 & 28.9 & 6.6 \\
\hline \multicolumn{10}{|l|}{17 Aug (230.91) } \\
\hline \multirow[t]{2}{*}{ SML(Lead) } & POM & 448.1 & - & 38.5 & 1.6 & 7.5 & 25.4 & 21.1 & 5.9 \\
\hline & HMW DOM & 1801.8 & & 38.0 & 1.6 & 7.0 & 39.3 & 10.5 & 3.5 \\
\hline \multirow[t]{2}{*}{ SSW(Lead) } & POM & 64.2 & 1.1 & 27.6 & 1.1 & 2.5 & 17.5 & 40.5 & 10.8 \\
\hline & HMW DOM & 148.8 & & 35.7 & 0.9 & 2.9 & 43.7 & 12.3 & 4.5 \\
\hline \multicolumn{10}{|l|}{26 Aug (239.44) } \\
\hline \multirow[t]{2}{*}{ SML(Lead) } & POM & 135.3 & 3.1 & 16.5 & 5.2 & 18.4 & 6.9 & 43.2 & 10.0 \\
\hline & HMW DOM & 588.9 & & 14.9 & 5.8 & 9.9 & 21.7 & 33.7 & 13.9 \\
\hline \multirow[t]{2}{*}{ SSW(Lead) } & POM & 80.3 & 0.6 & 13.6 & 3.5 & 13.5 & 7.0 & 42.0 & 20.5 \\
\hline & HMW DOM & 55.7 & & 24.2 & 2.7 & 8.2 & 24.4 & 30.1 & 10.4 \\
\hline \multicolumn{10}{|l|}{29 Aug (242.44) } \\
\hline \multirow[t]{2}{*}{ SML(Lead) } & POM & 142.6 & 2.5 & 18.5 & 3.2 & 13.2 & 7.0 & 38.3 & 19.9 \\
\hline & HMW DOM & 357.7 & & 22.5 & 1.0 & 6.4 & 20.4 & 42.3 & 7.4 \\
\hline \multirow[t]{2}{*}{ SSW(Lead) } & POM & 77.4 & 0.7 & 25.3 & 2.0 & 8.5 & 14.4 & 36.4 & 13.4 \\
\hline & HMW DOM & 102.5 & & 30.2 & 1.2 & 4.2 & 19.3 & 32.0 & 13.1 \\
\hline \multicolumn{10}{|l|}{21 Aug (234.44) } \\
\hline \multirow[t]{2}{*}{ New ice(Lead) } & POM & 177.0 & 2.8 & 13.7 & 0.9 & 3.1 & 2.3 & 76.5 & 3.6 \\
\hline & HMW DOM & 2285.5 & & 32.9 & 0.2 & 1.5 & 61.9 & 2.0 & 1.5 \\
\hline Ice algal assemblage & & & & 27.3 & 0.5 & 1.9 & 61.0 & 7.5 & 1.9 \\
\hline
\end{tabular}

* Percentage of sum of THNS (POM + HMW DOM) to TOC.

collected during the OW and MIZ stations (Table 5) exhibited distinct monosaccharide spectra, with relatively higher contributions of arabinose and galactose compared to the open lead samples. Such differences in monosaccharide distributions might result from variability in biological microalgal and bacterial species and related physiology in the open water and first- and multi-year ice-covered seawater in the pack ice.

The general pattern of monosaccharide composition in HMW DOM was similar to that in POM. Some differences in the relative mole percentage of fucose opposed to rhamnose were observed. HMW DOM was enriched in fucose $(29.3 \pm 9.2 \%)$ and depleted in rhamnose $(5.3 \pm 2.3 \%)$ compared to POM where the contribution of the two deoxy sugars was approximately equal $(13.1 \pm 6.2 \%$ for fucose and $9.6 \pm 4.4 \%$ for rhamnose). In addition, polysaccharides in the POM fraction were slightly enriched in glucose + mannose $(36.3 \pm 10.4 \%)$ compared to the HMW DOM fraction (23.6 \pm $9.3 \%)$. The distinct pattern between HMW DOM and POM was extremely evident in the fresh ice sample with $61.9 \%$ 
of fucose in HMW DOM and $76.5 \%$ of glucose + mannose in POM fraction. The high percentage of glucose + mannose in POM could be related to the glucose polymers (glucan or glycoprotein) in structural polysaccharides as suggested by other studies (Pakulski and Benner, 1994; Panagiotopoulos and Sempere, 2005; Skoog and Benner, 1998).

The monosaccharide composition of SML samples was nearly identical to the SSW samples, even though the THNS concentration in SML varied considerably from one day to the next. This might be indicative that in situ production by microorganisms in the underlying seawater or nearby sea ice may be an extremely important source for the SML polysaccharides. The exclusively predominant fucose $(61 \%)$ in the ice algae assemblage suggested a primary source of extracellular polysaccharides with an ice algal origin (Table 5). The substantial xylose $(27.3 \%)$ in the ice algae assemblage probably indicates that these two monosaccharides (fucose and xylose) are either associated together as heteropolysaccharides (i.e., fucoxylan) or appear as homopolysaccharides (i.e., fucoidans and xylans) (Handa and Yanagi, 1969).

In this study, the observed monosaccharide spectra (relative percentage of monosaccharides) over different sizes of organic matter were similar to those reported from the central Arctic (Rich et al., 1997) as well as from lower latitude temperate waters, such as the Gulf of Mexico, Atlantic and Pacific Ocean (Benner et al., 1997; Kaiser and Benner, 2009; Gogou and Repeta, 2010). Most of these studies showed that arabinose was the least abundant sugar while the other 6 monosaccharides were nearly equally abundant, although variations in relative monosaccharide abundance were observed due to differences in local DOM sources and removal processes. The resemblance of monosaccharide spectra among different sampling sites suggested that the processes responsible for the formation of biomolecules must be highly specific on a global basis (Aluwihare et al., 1997). Briefly, it was shown that polysaccharides rich in deoxy sugars including rhamnose and fucose are mostly acidic/anionic polymers with uronic acids (glucuronic acid and galacturonic acid) or sulfate ester groups associated (Decho, 1990; Mopper et al., 1995; Zhou et al., 1998). The association of deoxy sugars and anionic function groups in the polysaccharides could be important to regulate the production of aggregates. The lower fraction of rhamnose in the open lead samples relative to the results of Zhou et al. (1998) may reflect the different species of planktonic diatoms encountered in the two studies. For example, the sea-ice diatom Melosira arctica, abundant underneath the ice floe at our pack ice site (Orellana et al., 2011) and others (Melnikov, 1997), likely has a different physiology and biochemical composition than the planktonic diatom Chaetoceros gracilis studied by Zhou et al. (1998).

\section{Bubble scavenging of polysaccharides and its implication for aerosol formation}

As proposed by Bigg and Leck (2008), highly surface active EPS and embedded solid particles such as bacteria, phytoplankton and their detritus could be selectively carried to the SML by rising bubbles. Simple biological sugars, bacteria and phytoplankton cells have also been observed to be several orders of magnitude enriched in the SML as well as in the nascent particles produced through bubble bursting (Keene et al., 2007; Kuznetsova et al., 2005; Russell et al., 2009). That a rising bubble within the ocean water column can scavenge and transfer organic materials to the atmosphere upon bursting was suggested early on by Blanchard (1975).

\subsection{Scavenging of polysaccharides at the air-water interface}

Within the first half hour of bubbling, foam was readily formed and occasionally amorphous aggregates became visible on the wall as bubbles accumulated at the surface of the seawater in the experimental glass tower. In general, the THNS concentration within the foam layer was 1-2 orders of magnitude higher than the reference seawater used for bubbling (Table 6). The increase of THNS concentration in the foam layer coincided with a decrease of THNS in the residual seawater. This result provides evidence that the polysaccharides in bulk water can be carried by rising bubbles and accumulated at the air-water interface. The removal of THNS (indicated by $\%$ loss; Table 6 ) from the source water reflects that $31-63 \%$ of the polysaccharides exhibited surface active properties. Mass balance calculations, defined as the percentage of total amount of THNS (residual water + foam layer) after bubbling to those initially existent in source bulk water before bubbling, were used to indicate the formation of new aggregates or the loss of "old" particles (i.e., by disaggregation, dissolution or adsorption onto the wall of glass tower). The results in Table 6 show that the bubbling process itself formed a remarkable fraction of new polysaccharide aggregates abiotically. The number of newly formed colloidal particles (HMW DOM) from dissolved precursors $(<5 \mathrm{kDa}$, equivalent to a $<5 \mathrm{~nm}$ ) might be even larger than that reported in Table 6, because they can be either aggregated further to form new particles $(>0.22 \mu \mathrm{m}$ diameter) or be transported into to the air as nascent aerosol particles (see discussion below). The newly formed colloids imply that some short-chain oligosaccharides in the nanometerlength scale might represent an important pool for the formation of microcolloids/particles through bubbling. It has been well documented that freshly released polymers can exist as fibrils of about $1 \mathrm{kDaMW}$ (equivalent to $1 \mathrm{~nm}$ in diameter), which may assemble and form loose aggregations (Buffle and Leppard, 1995; Decho, 1990). The abundance of microcolloids observed at the open lead site (Orellana 
Table 6. Total hydrolysable neutral sugars (THNS) concentration (nM) in the particulate (POM) and high molecular weight dissolved (HMW DOM) organic matter fractions of foam and aerosol particles generated by bubbling experiment as well as the residual, bubbled seawater. Also shown for comparison are concentrations in unsparged seawater (reference).

\begin{tabular}{|c|c|c|c|c|c|c|c|c|c|}
\hline \multirow{2}{*}{ Sample } & \multicolumn{2}{|c|}{ Foam } & \multicolumn{2}{|c|}{$\begin{array}{l}\text { Residual seawater } \\
\left(\% \operatorname{loss}^{\mathrm{a}}\right)\end{array}$} & \multicolumn{2}{|c|}{ Reference seawater } & \multirow{2}{*}{$\begin{array}{l}\text { Aerosol } \\
\text { particles }\end{array}$} & \multicolumn{2}{|c|}{$\%$ Mass balance } \\
\hline & POM & $\begin{array}{l}\text { HMW } \\
\text { DOM }\end{array}$ & POM & $\begin{array}{l}\text { HMW } \\
\text { DOM }\end{array}$ & POM & $\begin{array}{l}\text { HMW } \\
\text { DOM }\end{array}$ & & POM & $\begin{array}{l}\text { HMW } \\
\text { DOM }\end{array}$ \\
\hline $\begin{array}{l}4 \text { Aug (217.52) } \\
\text { MIZ }\end{array}$ & 2877.6 & 7666.8 & $50.0(63)$ & 196.9 (32) & 134.7 & 288.5 & - & 65 & 103 \\
\hline $\begin{array}{l}14 \text { Aug (227.46) } \\
\text { Pack ice }\end{array}$ & 1245.3 & 4579.7 & $34.7(31)$ & $44.2(30)$ & 50.3 & 62.7 & 7870.1 & 101 & 165 \\
\hline $\begin{array}{l}17 \text { Aug (230.60) } \\
\text { Pack ice }\end{array}$ & 1610.0 & 19200.2 & $42.0(35)$ & $50.9(66)$ & 64.2 & 148.8 & 4852.3 & 98 & 203 \\
\hline $\begin{array}{l}29 \text { Aug }(242.45) \\
\text { Pack ice }\end{array}$ & 9567.0 & 10070.5 & $28.6(61)$ & $37.1(64)$ & 77.4 & 102.5 & 5683.9 & 198 & 165 \\
\hline
\end{tabular}

a $\%$ Loss given in parentheses is defined as $100 \%$. (reference seawater - residual seawater)/reference seawater. ${ }^{\mathrm{b}}$ Mass balance is defined as the percentage of the total amount of THNS (residual + foam layer, in mol) to the reference seawater. The volumes used to calculate the amount of THNS are 15.31 for residual and reference seawater; $200 \mathrm{ml}$ for foam water.

et al., 2011) could therefore have resulted from either separate physical, chemical and biological processes or in combination. Using the current TFF ultrafiltration method might therefore have missed out on the smaller colloidal fraction of THNS. Looking forward, it appears that bubbling of bulk seawater may serve as an efficient method to obtain colloids smaller than the sizes traditionally retained by ultrafiltration. The relative lower abundance of newly formed colloidal particles collected at the MIZ (Table 6) is probably related to the difference in biological activity and freshness of EPS with respect to the open lead. The formation of new particles by bubbling has been found to be less efficient for "aged" colloidal precursors with lower bioreactivity (Zhou et al., 1998). It was also reported that the efficiency of aggregate formation is largely dependent upon the initial size of the dispersed materials (Johnson et al., 1986), with older polymers being shorter (Orellana and Verdugo, 2003). Nevertheless, the bioreactivity and, to a large extent, the surface active properties of polysaccharides are closely associated with their chemical composition. The resemblance of monosaccharide spectra observed between the foam-fraction and the SML samples (Fig. 4) implied that fucose-enriched polysaccharides exhibited a strong tendency to be adsorbed on the surface of a rising bubble and were preferentially transferred into the SML. This finding is supportive of the suggested (Bigg and Leck, 2008; Kuznetsova et al., 2005; Russell et al., 2011) existence of a bubble-mediated mechanism for the accumulation of surface active materials in the SML.

It has been proposed that the efficiency of aggregate formation by bubble adsorption depends on the properties of bubbles, including size and number concentration (Andreas and Monahan, 2000; Blanchard, 1975). In a parallel study at the open lead, Norris et al. (2011) demonstrated the presence of a significant number of bubbles with size of 30

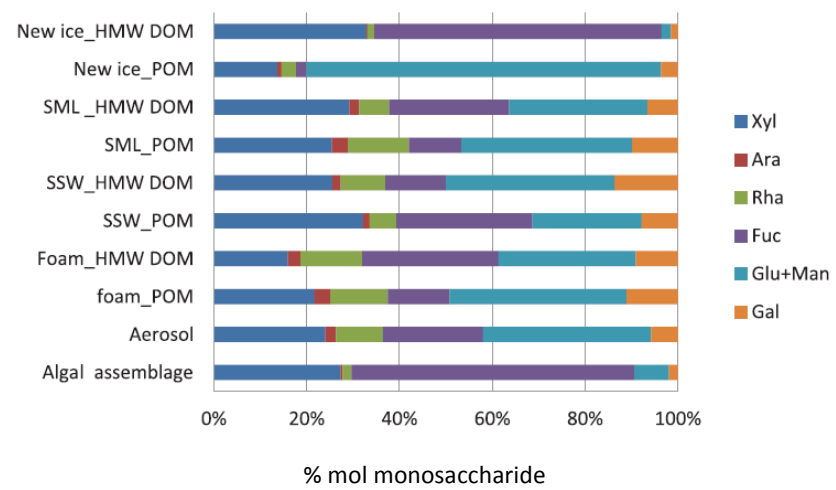

Fig. 4. Relative mole percentage of monosaccharides (\% mol) in new ice, surface microlayer (SML), subsurface seawater (SSW), foam layer, aerosols and algal assemblage. Shown are xylose (Xyl), arabinose (Ara), rhamnose (Rha), fucose (Fuc), the sum of glucose (Glu) and mannose (Man), and galactose (Gal) in the high molecular weight dissolved (HMW DOM) and particulate (POM) organic matter, except aerosol and algal assemblage which were not fractionated (See Sects. 2.3 and 2.5).

$100 \mu \mathrm{m}$ in diameter, which were similar to those observed in temperate open water regions under breaking wave conditions; though larger (ca. $300 \mu \mathrm{m}$ diameter) than the dominant in situ bubble population, the experimentally generated bubble sizes were clearly in the range $(30-560 \mu \mathrm{m})$ of the open lead bubbles. Johnson et al. (1986) showed that small bubbles $(<200 \mu \mathrm{m}$ in diameter), with longer resident time in seawater, were less effective for the coagulation of colloids than larger bubbles. We therefore hypothesize that the relatively smaller bubbles present in the surface waters of the lead may, on one hand, have given the microcolloids a longer residence time by preventing aggregation and any subsequent 
sinking of any resulting larger particles. On the other hand, the bubble population may have been sufficient to initiate upward transport of the buoyant nano- and microcolloids to the air-sea interface (upper most surface water).

\subsection{Bubble adsorption of polysaccharides and their transformation at the sea-air interface}

A concurrence of substantial numbers of bubbles with microcolloids attached is important because the bubbles, upon bursting at the sea-air interface, could provide a mechanism for the transfer of microcolloids from the ocean SML into the atmosphere (Bigg and Leck, 2008; Leck and Bigg, 2005a, b; Russell et al., 2009; Orellana et al. 2011). Hoffman and Duce (1976) noted that the efficiency to transfer organics from sea to air via bubble bursting was positively correlated with the path length of rising bubbles and therefore their stability. The THNS detected in the nascent aerosol samples generated by the bubbling experiment demonstrated the presence of an active water-to-air flux of polymeric substances (Table 6). By assuming that $1 \mathrm{ml}$ of seawater impacted the glass plate during bubbling, we can estimate that the THNS in the experimental aerosol samples, with concentrations ranging from 4852 to $7870 \mathrm{nM}$ (Table 6), was enriched relative to the source seawater by factors of 22 70 . The mean relative mol $\%$ of monosaccharides in field aerosol samples (from DOY 227, 1st period; 230, 1st period; and 242 , 3rd period) is given in Fig. 4. By comparing the relative contribution of fucose vs. rhamnose as well as the percentage of glucose + mannose, which we used to differentiate the POM and the HMW DOM, the nascent aerosol particles resembled the HMW DOM and, to some extent, the POM as well. This suggests that bubble bursting might carry both a substantial fraction of microcolloidal matter and their aggregate products from the SML into atmosphere. Our observations agree with Kuznetsova et al. (2005), who reported enrichment of organic matter in aerosols, including TEP ( $\mathrm{EF}=44 \pm 22$ ) and amino acids (up to 50-fold). Furthermore, polysaccharides-containing aerosols exist not only over the central Arctic Ocean, but also over temperate and subtropical oceans (Leck and Bigg, 2008; Russell et al., 2009), where a significant fraction of carbohydrates (7-20\% of organic mass) in organic aerosol particles can be ocean-derived (Crahan et al., 2004). The processes responsible for the bubble production and particle fragments include film drops and jet drops (Blanchard, 1963; Blanchard and Woodcock, 1957). The formation of airborne particles by film droplets (centered on $100 \mathrm{~nm}$ diameter) constitutes the largest contribution to $\mathrm{CCN}$ number concentrations, particularly in remote marine areas (Lohmann and Leck, 2005; O'Dowd et al., 2004). However, the nascent aerosol particles artificially generated in our study were bulk collected without size segregation. Therefore, the relative abundance of film droplets or jet drops generated during the bubbling experiment remains uncertain. Nevertheless, the monosaccharide composition of the bubble generated aerosol particles indicates that a large fraction of these spray particles was derived from organic polymers representing a colloidal size fraction. It is noteworthy that the bubble property in our bubbling experiment may differ from the bubble spectra observed during typical conditions at the open lead site. Bubbles generated mechanically in the glass column apparently had both higher rising velocity and slightly larger bubble sizes compared to the in situ naturally occurring bubbles (Norris et al., 2011). The visible foam layer and rising bubbles in the present experiment were never noticeable in the open leads during sampling, which implies that the bubble production generated experimentally could be much higher than that naturally occurring in open leads. Norris et al. (2011) estimated that the bubble flux at the open lead varied approximately from $0.1 \times 10^{4}$ to $2 \times 10^{4} \mathrm{~m}^{-2} \mathrm{~s}^{-1}$, based on calculations of bubble terminal rise velocity and bubble size spectra. Given the controlled air flow rate and bubble sizes in our bubbling experiment, the laboratory number flux can be estimated to be about 2 orders of magnitude higher. Previous studies (Hoffman and Duce, 1976; Keene et al., 2007; Tseng et al., 1992) have demonstrated by similar laboratory bubble production experiments (via air flow) that the sea-to-air flux is proportional to the rate at which the organics are transferred to the surface by rising bubbles. Their results also showed that the sea-to-air flux of organics increases with the increasing path length of rising bubbles and with decreasing bubble size. Furthermore, higher water temperature present under our experimental conditions (about $4{ }^{\circ} \mathrm{C}$ ) might also have a positive effect on the dissolution of microbubbles. Olli et al. (2007) showed that most of biological activity took place in the upper $5 \mathrm{~m}$ of the ocean surface mixed layer at the open lead. Given the potential differences in bubble properties, and if bubbles are responsible for the accumulation of organics in the SML and subsequent sea-to-air transformation as demonstrated in the present study, the enrichment of polysaccharides in SML as well as in the nascent aerosol particles obtained in our experimental simulation could be enhanced and overestimated compared to the typical conditions in the open lead. Caution should be taken in making a quantitative extrapolation of the resulting data to field conditions. Future studies should be conducted to quantify the ejection of SML organics and enrichment of polysaccharides by bubbles insitu in open leads. It is also noteworthy that the typical low wind speeds recorded at Arctic open leads may facilitate the enrichment of organics at the air-sea interface through effective formation of SML and probably constrain primary sea spray production. As a result, the enrichment and dynamic pattern of polysaccharides (i.e., the magnitude of accumulation/disruption of polysaccharides in SML) observed at the Arctic open leads will differ from those in regions where wind-induced, breaking waves prevail (Gantt et al., 2011). 


\section{Summary and conclusion}

The central Arctic Ocean pack ice area was characterized by generally high concentration of TOC, comprised of polysaccharides released by sea ice algae and phytoplankton. High concentrations of heteropolysaccharides with high surface activity (indicated by \% removal of THNS in the bubble experiments, Table 6) were common features of the exopolysaccharides present at the high Arctic open lead site sampled. Size fractionation of the organic polymeric materials in surface seawater showed varying patterns in their chemical composition and distribution between the SML and SSW. A small, but persistent, enrichment of TOC as well as sporadic depletions of dissolved carbohydrates and amino acids were observed in the SML; these patterns are consistent with observations in lower latitudes (Kuznetsova et al., 2004; Reinthaler et al., 2008). Our data indicated that the SML at the open lead site differed from its SSW not only in the concentration of organic matter, but also in its chemical composition. It has been recognized historically that organic matter in seawater exists in a continuum of sizes (Hansell and Carlson, 2002). Indeed, polysaccharides with high bioreactivity (indicated by NS yield) in the colloidal organic pool (HMW DOM) were preferentially concentrated in the SML, relative to the truly dissolved and particulate organic matter fractions. Furthermore, the SML enrichment factors of TOC indicate a strong tendency for organic matter to be accumulated at the air-sea interface, for which rising bubbles and surface coagulation of polymer microgels are the likely causes. The prevalence of the colloidal fraction polysaccharides observed in our study, the high concentration of microgels within the SML (Orellana et al., 2011), and the polysaccharide enrichment of our experimentally generated aerosols suggest that particulate matter enriched in biogenic polysaccharides might represent a potentially important reactive medium in a number of air-sea exchange processes, including $\mathrm{CCN}$ formation and cloud droplet activation in the central Arctic.

Acknowledgements. This work is part of ASCOS (the Arctic Summer Cloud Ocean Study). ASCOS was made possible by funding from the Knut and Alice Wallenberg Foundation and the DAMOCLES European Union 6th Framework Program Integrated Research Project. The Swedish Polar Research Secretariat (SPRS) provided access to the icebreaker R/V Oden and logistical support. Michael Tjernström and Caroline Leck are specifically thanked for their coordination of ASCOS. We are grateful to the SPRS logistical staff and to R/V Oden's Captain Mattias Peterson and his crew. ASCOS is an IPY project under the AICIA-IPY umbrella and an endorsed SOLAS project. Support for this work was provided by the Swedish Research Council (VR) and the Knut and Alice Wallenberg Foundation (QG, CL) as well as by the US National Science Foundation (OPP ANS) to PAM and CR.

Edited by: I. Brooks
References

Aluwihare, L. I., Repeta, D. J., and Chen, R. F.: A major biopolymeric component to dissolved organic carbon in surface sea water, Nature, 387, 166-169, 1997.

Amon, R. M. W. and Benner, R.: Combined neutral sugars as indicators of the diagenetic state of dissolved organic matter in the Arctic Ocean, Deep-Sea Res. Pt. I, 50, 151-169, 2003.

Andreas, E. L. and Monahan, E. C.: The role of whitecap bubbles in air-sea heat and moisture exchange, J. Phys. Oceanogr., 30, 433-442, 2000.

Azetsu-Scott, K. and Passow, U.: Ascending marine particles: Significance of transparent exopolymer particles (TEP) in the upper ocean, Limnol. Oceanogr., 49, 741-748, 2004.

Benner, R., Pakulski, J. D., McCarthy, M., Hedges, J. I., and Hatcher, P. G.: Bulk chemical characteristics of dissolved organic-matter in the ocean, Science, 255, 1561-1564, 1992.

Benner, R., Biddanda, B., Black, B., and McCarthy, M.: Abundance, size distribution, and stable carbon and nitrogen isotopic compositions of marine organic matter isolated by tangential-flow ultrafiltration, Mar. Chem., 57, 243-263, 1997.

Bigg, E. K. and Leck, C.: The composition of fragments of bubbles bursting at the ocean surface, J. Geophys. Res., 113, D11209, doi:10.1029/2007JD009078, 2008.

Bigg, E., Leck, C., and Tranvik, L.: Particulates of the surface microlayer of open water in the central Arctic Ocean in summer, Mar. Chem., 91, 131-141, 2004.

Blanchard, D. C.: The electrification of the atmosphere by particles from bubbles in the sea, Prog. Oceanogr., 1, 73-202, 1963.

Blanchard, D. C.: Bubble scavenging and the water to air transfer of organic material in the sea, Appiled chemistry at protein interfaces, Adv. Chem. Ser., 145, Amer. Chem. Soc., Washington, 1975.

Blanchard, D. C. and Woodcock, A. H.: Bubble formation and modification in the sea and its meteorological significance, Tellus, 9, 145-158, 1957.

Brierley, A. S. and Thomas, D. N.: Ecology of Southern Ocean pack ice, Adv. Mar. Biol., 43, 171-276, 2002.

Buffle, J. and Leppard, G. G.: Characterization of aquatic colloids and macromolecules. 1. Structure and behavior of colloidal material, Environ. Sci. Technol., 29, 2169-2175, 1995.

Chin, W.-C., Orellana, M. V., and Verdugo, P.: Spontaneous assembly of marine dissolved organic matter into polymer gels, Nature, 391, 568-572, 1998.

Clayton, J. R., Dortch, Q., Thoresen, S. S., and Ahmed, S. I.: Evaluation of methods for the separation and analysis of proteins and free amino acids in phytoplankton samples, J. Plankton Res., 10, 341-358, 1988.

Cowie, G. L. and Hedges, J. I.: Determination of neutral sugars in plankton, sediments, and wood by capillary gas chromatography of equilibrated isomeric mixtures, Anal. Chem., 56, 497-504, 1984.

Crahan, K. K., Hegg, D. A., Covert, D. S., Jonsson, H., Reid, J. S., Khelif, D., and Brooks, B. J.: Speciation of organic aerosols in the tropical mid-Pacific and their relationship to light scattering, J. Atmos. Sci., 61, 2544-2558, 2004.

Decho, A.: Microbial exopolymer secritions in ocean environment: Their role(s) in food webs and marine processes, Oceanogr. Mar. Biol., 28, 73-153, 1990. 
Deming, J. W.: Sea ice bacteria and viruses, in: Sea Ice - an introduction to its physics, chemistry, biology and geology, edited by: Thomas, D. N. and Dieckmann, G. S., 2nd Edn., Blackwell Science Ltd, Oxford, 247-282, 2010.

Dortch, Q., Clayton Jr., J. R., Thoresen, S. S., and Ahmed, S. I.: Species differences in accumulation of nitrogen pools in phytoplankton, Mar. Biol., 81, 237-250, 1984.

Engbrodt, R. and Kattner, G.: On the biogeochemistry of dissolved carbohydrates in the Greenland Sea (Arctic), Org. Geochem., 36, 937-948, 2005.

English, T. S.: Some biological oceanographic observations in the central North Polar Sea, Drift Station Alpha, 1957-1958, Arctic Inst. N. Am. Res. Pap., 13, 64-79, 1961.

Fuentes, E., Coe, H., Green, D., and McFiggans, G.: On the impacts of phytoplankton-derived organic matter on the properties of the primary marine aerosol - Part 2: Composition, hygroscopicity and cloud condensation activity, Atmos. Chem. Phys., 11, 25852602, doi:10.5194/acp-11-2585-2011, 2011.

Gantt, B., Meskhidze, N., Facchini, M. C., Rinaldi, M., Ceburnis, D., and O'Dowd, C. D.: Wind speed dependent size-resolved parameterization for the organic mass fraction of sea spray aerosol, Atmos. Chem. Phys., 11, 8777-8790, doi:10.5194/acp-11-87772011, 2011

Gao, Q., Araia, M., Leck, C., and Emmer, A.: Characterization of exopolysaccharides in marine colloids by capillary electrophoresis with indirect UV detection, Anal. Chim. Acta., 662, 193-199, 2010.

Gao, Q., Nilsson, U., Ilag, L. L., and Leck, C.: Monosaccharide compositional analysis of marine polysaccharides by hydrophilic interaction liquid chromatography-tandem mass spectrometry, Anal. Bioanal. Chem., 399, 2517-2529, 2011.

Giannelli, V., Thomas, D. N., Haas, C., Kattner, G., Kennedy, H., and Dieckmann, G. S.: Behaviour of dissolved organic matter and inorganic nutrients during experimental sea-ice formation, Ann. Glaciol., 33, 317-321, 2001.

Gogou, A. and Repeta, D. J.: Particulate-dissolved transformations as a sink for semi-labile dissolved organic matter: Chemical characterization of high molecular weight dissolved and surfaceactive organic matter in seawater and in diatom cultures, Mar. Chem., 121, 215-223, 2010.

Goldberg, S. J., Carlson, C. A., Brzezinski, M., Nelson, N. B., and Siegel, D. A.: Systematic removal of neutral sugars within dissolved organic matter across ocean basins, Geophys. Res. Lett., 38, L17606, doi:10.1029/2011GL048620, 2011.

Handa, N. and Yanagi, K.: Studies on water-extractable carbohydrates of the particulate matter from the northwest Pacific Ocean, Mar. Biol., 4, 197-207, 1969.

Hansell, D. A. and Carlson, C. A.: Biogeochemistry of marine dissolved organic matter, Academic Press, San Diego, CA, 2002.

Henrichs, S. M. and Williams, P. M.: Dissolved and particulate amino acids and carbohydrates in the sea surface microlayer, Mar. Chem., 17, 141-163, 1985.

Hoffman, E. J. and Duce, R. A.: Factors influencing the organic carbon content of marine aerosols: a laboratory study, J. Geophys. Res., 81, 3667-3670, 1976.

Holm-Hansen, O., Lorenzen, C. J., Holmes, R. W., and Strickland, J. D. H.: Fluorometric determination of chlorophyll, J. Conseil, Intern. Exploration Mer., 30, 3-15, 1965.
Hung, C. C., Tang, D., Warnken, K. W., and Santschi, P. H.: Distributions of carbohydrates, including uronic acids, in estuarine waters of Galveston Bay, Mar. Chem., 73, 305-318, 2001.

Hung, C. C., Guo, L., Santschi, P. H., Alvarado-Quiroz, N., and Haye, J. M.: Distributions of carbohydrate species in the Gulf of Mexico, Mar. Chem., 81, 119-135, 2003.

Intrieri, J.M., Shupe, M. D., Uttal, T., and McCarty, B. J.: An annual cycle of Arctic cloud characteristics observed by radar and lidar at SHEBA, J. Geophys. Res., 107, 8030, doi:10.1029/2000JC000423, 2002.

Johnson, B. D., Zhou, X., and Wangersky, P. J.: Surface coagulation in sea water, Neth. J. Sea Res., 20, 201-210, 1986.

Kaiser, K. and Benner, R.: Biochemical composition and size distribution of organic matter at the Pacific and Atlantic time-series stations, Mar. Chem., 113, 63-77, 2009.

Keene, W. C., Maring, H., Maben, J. R., Kieber, D. J., Pszenny, A. A. P., Dahl, E. E., Izaguirre, M. A., Davis, A. J., Long, M. S., Zhou, X., Smoydzin, L., and Sander, R.: Chemical and physical characteristics of nascent aerosols produced by bursting bubbles at a model air-sea interface, J. Geophys. Res., 112, D21202, doi:10.1029/2007JD008464, 2007.

Keil, R. G. and Kirchman, D. L.: Dissolved combined amino acids in marine waters as determined by a vapor-phase hydrolysis method, Mar. Chem., 33, 243-259, 1991.

Kerherve, P., Buscail, R., Gadel, F., and Serve, L.: Neutral monosaccharides in surface sediments of the Northwestern Mediterranean sea, Org. Geochem., 33, 421-435, 2002.

Knap, A. H., Michaels, A. E., Close, A., Ducklow, H. W., and Dickson, A. G. (Eds.): Protocols for the Joint Global Ocean Flux Study (JGOFS) core measurements. JGOFS Report No. 19, Bergen, Norway, 1996.

Knulst, J. C., Rosenberger, D., Thompson, B., and Paatero, J.: Intensive sea surface microlayer investigations of open leads in the pack ice during Arctic Ocean 2001 expedition, Langmuir, 19, 10194-10199, 2003.

Krembs, C. and Deming, J. W.: The role of exopolymers in micrbial adaption to sea ice, Psychrophiles: From biodiversity to biotechnology, Springer, Heidelberg, 247-264, 2008.

Krembs, C. and Engel, A.: Abundance and variability of microorganisms and transparent exopolymer particles across the icewater interface of melting first-year sea ice in the Laptev Sea (Arctic), Mar. Biol., 138, 173-185, 2001.

Krembs, C., Eicken, H., Junge, K., and Deming, J. W.: High concentrations of exopolymeric substances in Arctic winter sea ice: implications for the polar ocean carbon cycle and cryoprotection of diatoms, Deep-Sea Res., 49, 2163-2181, 2002.

Kuznetsova, M., Lee, C., Aller, J., and Frew, N.: Enrichment of amino acids in the sea surface microlayer at coastal and open ocean sites in the North Atlantic Ocean, Limnol. Oceanogr., 49, 1605-1619, 2004.

Kuznetsova, M., Lee, C., and Aller, J.: Characterization of the proteinaceous matter in marine aerosols, Mar. Chem., 96, 359-377, 2005.

Leck, C. and Bigg, E. K.: Aerosol production over remote marine areas - A new route, Geophys. Res. Lett., 26, 3577-3580, 1999.

Leck, C. and Bigg, E. K.: Biogenic particles in the surface microlayer and overlaying atmosphere in the central Arctic Ocean during summer, Tellus B, 57, 305-316, 2005a. 
Leck, C. and Bigg, E. K.: Source and evolution of the marine aerosol - A new perspective, Geophys. Res. Lett., 32, 1-4, 2005 b.

Leck, C. and Bigg, E. K.: Comparison of sources and nature of the tropical aerosol with the summer high Arctic aerosol, Tellus B, 60, 118-126, 2008.

Leck, C. and Bigg, E. K.: New particle formation of marine biological origin, Aerosol Sci. Tech., 44, 570-577, 2010.

Leck, C. and Persson, C.: The central Arctic Ocean as a source of dimethyl sulfide Seasonal variability in relation to biological activity, Tellus B, 48, 156-177, 1996.

Leck, C., Norman, M., Bigg, E .K., and Hillamo, R.: Chemical composition and sources of the high Arctic aerosol relevant for cloud formation, J. Geophys. Res., 107, 4135, doi:10.1029/2001JD001463, 2002.

Liss, P. S. and Duce, R. A.: The Sea surface and global change, Cambridge University Press, 1997.

Lohmann, U. and Leck, C.: Importance of submicron surface-active organic aerosols for pristine Arctic clouds, Tellus B, 57, 261268, 2005.

Loose, B., Miller, L. A., Elliott, S., and Papakyriakou, T.: Sea ice biogeochemistry and material transport across the frozen interface, Oceanography, 24, 202-218, 2011.

Martin, M., Chang, R. Y.-W., Sierau, B., Sjogren, S., Swietlicki, E., Abbatt, J. P. D., Leck, C., and Lohmann, U.: Cloud condensation nuclei closure study on summer arctic aerosol, Atmos. Chem. Phys., 11, 11335-11350, doi:10.5194/acp-11-11335-2011, 2011.

Matrai, P. A., Tranvik, L., Leck, C., and Knulst, J. C.: Are high Arctic surface microlayers a potential source of aerosol organic precursors?, Mar. Chem., 108, 109-122, 2008.

McCarthy, M., Hedges, J., and Benner, R.: Major biochemical composition of dissolved high molecular weight organic matter in seawater, Mar. Chem., 55, 281-297, 1996.

Melnikov, I. A.: The Arctic sea ice ecosystem, Gordon and Breach Science Publishers, Netherland, 1997.

Mopper, K. and Dawson, R.: Determination of amino acids in seawater - Recent chromatographic developments and future directions, Sci. Total Environ., 49, 115-131, 1986.

Mopper, K., Zhou, J., Ramana, K. S., Passow, U., Dam, H. G., and Drapeau, D. T.: The role of surface-active carbohydrates in the flocculation of a diatom bloom in a mesocosm, Deep-Sea Res., 42, 47-73, 1995.

Muller, S., Vähätalo, A. V., Granskog, M. A., Autio, R., and Kaartokallio, H.: Behaviour of dissolved organic matter during formation of natural and artificially grown Baltic Sea ice, Ann. Glaciol., 52, 233-241, 2011.

Norris, S. J., Brooks, I. M., de Leeuw, G., Sirevaag, A., Leck, C., Brooks, B. J., Birch, C. E., and Tjernström, M.: Measurements of bubble size spectra within leads in the Arctic summer pack ice, Ocean Sci., 7, 129-139, doi:10.5194/os-7-129-2011, 2011.

O'Dowd, C.D., Facchini, M. C., Cavalli, F., Cebumis, D., Mircea, M., Decesari, S., Fuzzi, S., Yoon., Y. J., and Putaud, J.-P.: Biogenically driven organic contribution to marine aerosol, Nature, 431, 676-680, 2004.

Olli, K., Wassmann, P., Reigstad, M., Ratkova, T. N., Arashkevich, E., Pasternak, A., Matrai, P. A., Knulst, J., Tranvik, L., Klais, R., and Jacobsen, A.: The fate of production in the central Arctic Ocean - top-down regulation by zooplankton expatriates, Prog. Oceanogr., 72, 84-113, 2007.
Orellana, M. V. and Verdugo, P.: Ultraviolet radiation blocks the organic carbon exchange between the dissolved phase and the gel phase in the ocean, Limnol. Oceanogr., 48, 1618-1623, 2003.

Orellana, M. V., Matrai, P. A., Leck, C., Rauschenberg, C. D., Lee, A. M., and Coz, E.: Marine microgels as a source of cloud condensation nuclei in the high arctic, P. Natl. Acad. Sci. USA., 108, 13612-13617, 2011.

Ovadnevaite, J., Ceburnis, D., Martucci, G., Bialek, J., Monahan, C., Rinaldi, M., Facchini, M. C., Berresheim, H., Worsnop, D. R., and O'Dowd, C.: Primary marine organic aerosol: A dichotomy of low hygroscopicity and high CCN activity, Geophys. Res. Lett., 38, L21806, doi:10.1029/2011GL048869, 2011.

Paatero, J., Vaattovaara, P., Vestenius, M., Meinander, O., Makkonen, U., Kivi, R., Hyvärinen, A., Asmi, E., Tjernström, M., and Leck, C.: Finnish contribution to the Arctic Summer Cloud Ocean Study (ASCOS) expedition, Arctic Ocean 2008, Geophysica, 45, 119-146, 2009.

Pakulski, J. D. and Benner, R.: Abundance and distribution of carbohydrates in the ocean. Limnol. Oceanogr., 39, 930-940, 1994.

Panagiotopoulos, C. and Sempere, R.: Analytical methods for the determination of sugars in marine samples: A historical perspective and future directions, Limnol. Oceanogr.-Meth., 3, 419-454, 2005.

Passow, U.: Transparent exopolymer particles (TEP) in aquatic environments, Prog. Oceanogr., 55, 287-333, 2002.

Redfield, A. C., Ketchum, B. H., and Richards, F. A.: The influence of organisms on the composition of seawater, in: The sea, Interscience, New York, 1963.

Reinthaler, T., Sintes, E., and Herndl, G. J.: Dissolved organic matter and bacterial production and respiration in the sea-surface microlayer of the open Atlantic and the western Mediterranean Sea, Limnol. Oceanogr., 53, 122-136, 2008.

Rich, J., Gosselin, M., Sherr, E., Sherr, B., and Kirchman, D. L.: High bacterial production, uptake and concentrations of dissolved organic matter in the Central Arctic Ocean, Deep-Sea Res., 44, 1645-1663, 1997.

Russell, L. M., Hawkins, L. N., Frossard, A. A., Quinn, P. K., and Bates, T. S.: Carbohydrate-like composition of submicron atmospheric particles and their production from ocean bubble bursting, P. Natl. Acad. Sci. USA., 107, 6652-6657, 2009.

Russell, L. M., Bahadur, R., and Ziemann, P. J.: Identifying organic aerosol sources by comparing functional group composition in chamber and atmospheric particles, P. Natl. Acad. Sci. USA., 108, 3516-3521, 2011.

Sedlar, J., Tjernström, M., Mauristen, T., Shupe, M. D., Brooks, I. M., Persson, P. O., Birch, C. E., Leck, C., Sirevaag, A., and Nicolaus, M.: A transitioning Arctic surface energy budget: the impacts of solar zenith angle, surface albedo and cloud radiative forcing, Clim. Dynam., 37, 1643-1660, 2011.

Sharp, J. H.: Analytical methods for dissolved organic carbon, nitrogen, and phosphorus, in: Biogeochemistry of Marine Dissolved Organic Matter, edited by: Hansell, D. A. and Carlson, C. A., Academic Press, San Diego, 2002.

Sieracki, M. E., Cucci, T. L., and Nicinski, J.: Flow cytometric analysis of 5-cyano-2,3-ditolyl tetrazolium chloride activity of marine bacterioplankton in dilution cultures, Appl. Environ. Microb., 65, 2409-2417, 1999.

Sirevaag, A., de la Rosa, S., Fer, I., Nicolaus, M., Tjernström, M., and McPhee, M. G.: Mixing, heat fluxes and heat content evo- 
lution of the Arctic Ocean mixed layer, Ocean Sci., 7, 335-349, doi:10.5194/os-7-335-2011, 2011.

Skoog, A. and Benner, R.: Aldoses in various size fractions of marine organic matter: Implications for carbon cycling, Limnol. Oceanogr., 42, 1803-1813, 1998.

Skoog, A., Alldredge, A., Passow, U., Dunne, J., and Murray, J.: Neutral aldoses as source indicators for marine snow, Mar. Chem., 108, 195-206, 2008.

Smith, W. O. and Nelson, D. M.: Phytoplankton Bloom Produced by a Receding Ice Edge in the Ross Sea: Spatial Coherence with the Density Field, Science, 227, 163-166, 1985.

Stolle, C., Nagel, K., Labrenz, M., and Jürgens, K.: Succession of the sea-surface microlayer in the coastal Baltic Sea under natural and experimentally induced low-wind conditions, Biogeosciences, 7, 2975-2988, doi:10.5194/bg-7-2975-2010, 2010.

Sverdrup, H. U.: On conditions for the vernal blooming of phytoplankton, J. Conseil, 18, 287-295, 1953.

Tseng, R.-S., Viechnicki, J. T., Skop, R. A., and Brown, J. W.: Seato-air transfer of surface-active organic compounds by bursting bubbles, J. Geophys. Res., 97, 5201-5206, 1992.

Underwood, G. J. C., Fietz, S., Papadimitriou, S., Thomas, D. N., and Dieckmann, G. S.: Distribution and composition of dissolved extracellular polymeric substances (EPS) in Antarctic sea ice, Mar. Ecol-Prog. Ser., 404, 1-19, 2010.

Verdugo, P., Alldredge, A. L., Azam, F., Kirchman, D. L., Passow, U., and Santschi, P. H.: The oceanic gel phase: A bridge in the DOM-POM continuum, Mar. Chem., 92, 67-85, 2004.
Verity, P., Wassmann, P., Ratkova, T., Andreassen, I., and Nordby, E.: Seasonal patterns in composition and biomass of autotrophic and heterotrophic nano- and microplankton communities on the north Norwegian shelf, Sarsia, 84, 265-277, 1999.

Wassmann, P. and Reigstad, M.: Future Arctic Ocean seasonal ice zones and implication for pelagic-benthic coupling, Oceanography, 24, 220-231, 2011.

Wells, M. L. and Goldberg, E. D.: Occurrence of small colloids in sea water, Nature, 353, 342-344, 1991.

Williams, P. M., Carlucci, A. F., Henrichs, S. M., Van Vleet, E. S., Horrigan, S. G., Reid, F. M. H., and Robertson, K. J.: Chemical and microbiological studies of sea-surface films in the Southern Gulf of California and off the West Coast of Baja California, Mar. Chem., 19, 17-98, 1986.

Wurl, O. and Holmes, M.: The gelatinous nature of the sea-surface microlayer, Mar. Chem., 110, 89-97, 2008.

Wurl, O., Miller, L., Röttgers, R., and Vagle, S.: The distribution and fate of surface-active substances in the sea-surface microlayer and water column, Mar. Chem., 115, 1-9, 2009.

Zhou, J., Mopper, K., and Passow, U.: The role of surface-active carbohydrates in the formation of transparent exopolymer particles by bubble adsorption of seawater, Limnol. Oceanogr., 43, 1860-1871, 1998. 